\title{
Nuclear export of metazoan replication-dependent histone mRNAs is dependent on RNA length and is mediated by TAP
}

\author{
JUDITH A. ERKMANN, ${ }^{1,2,3}$ RICARDO SÀNCHEZ,, ${ }^{1,2}$ NATHALIE TREICHEL, ${ }^{3}$ WILLIAM F. MARZLUFF, ${ }^{1,2}$ \\ and ULRIKE KUTAY ${ }^{3}$ \\ ${ }^{1}$ Program in Molecular Biology and Biotechnology and ${ }^{2}$ Department of Biochemistry and Biophysics, University of North Carolina, \\ Chapel Hill, North Carolina 27599 \\ ${ }^{3}$ Institute of Biochemistry, Swiss Federal Institute of Technology (ETH), Zurich, Switzerland
}

\begin{abstract}
Replication-dependent histone mRNAs are the only metazoan mRNAs that are not polyadenylated, ending instead in a conserved stem-loop sequence. Histone pre-mRNAs lack introns and are processed in the nucleus by a single cleavage step, which produces the mature $3^{\prime}$ end of the mRNA. We have systematically examined the requirements for the nuclear export of a mouse histone mRNA using the Xenopus oocyte system. Histone mRNAs were efficiently exported when injected as mature mRNAs, demonstrating that the process of $3^{\prime}$ end cleavage is not required for export factor binding. Export also does not depend on the stem-loop binding protein (SLBP) since mutations of the stem-loop that prevent SLBP binding and competition with a stem-loop RNA did not affect export. Only the length of the region upstream of the stem-loop, but not its sequence, was important for efficient export. Histone mRNA export was blocked by competition with constitutive transport element (CTE) RNA, indicating that the mRNA export receptor TAP is involved in histone mRNA export. Consistent with this observation, depletion of TAP from Drosophila cells by RNAi resulted in the restriction of mature histone mRNAs to the nucleus.
\end{abstract}

Keywords: nuclear transport; mRNA export; histone mRNA; SLBP; TAP

\section{INTRODUCTION}

Most metazoan mRNAs undergo splicing as part of their maturation process. However, a few genes, including the replication-dependent histone genes, do not contain introns, and hence splicing is not required for their biosynthesis. Replication-dependent histone mRNAs are also not polyadenylated. Rather, mature $3^{\prime}$ ends are formed by cleavage after a highly conserved stem-loop sequence (for review, see Dominski and Marzluff 1999). This process requires two cis elements, the stem-loop and an element downstream of the cleavage site termed the histone downstream element (HDE) (Dominski and Marzluff 1999). Two trans-acting factors needed for histone pre-mRNA cleavage are the stem-loop binding protein (SLBP) and the U7 small nuclear ribonucleoprotein particle (snRNP) (Dominski and

Reprint requests to: Ulrike Kutay, Institute of Biochemistry, Swiss Federal Institute of Technology (ETH), Zurich, Switzerland; e-mail: ulrike.kutay@bc.biol.ethz.ch; fax: +41-1-632 1591.

Article and publication are at http://www.rnajournal.org/cgi/doi/ 10.1261/rna.7189205.
Marzluff 1999). Following cleavage, the mature histone message is rapidly exported to the cytoplasm (Schochetman and Perry 1972).

Mammalian genomes contain about 65 nonallelic replication-dependent histone genes, encoding the four core histones and histone $\mathrm{H1}$, all of which end in the conserved stem-loop sequence (Marzluff et al. 2002). Replication-dependent histone mRNAs accumulate exclusively during $\mathrm{S}$ phase and encode the bulk of the histones that package newly replicated DNA into chromatin (Dominski and Marzluff 1999). Besides the replication-dependent histone genes, metazoans also have replication-independent histone genes, which are expressed throughout the cell cycle. The mRNAs produced from these genes are polyadenylated and encode the replacement variant histone proteins $\mathrm{H} 3.3$ and H2A.Z (Wells and Kedes 1985; Ahmad and Henikoff 2002; Redon et al. 2002).

A number of macromolecules and macromolecular complexes exported from the nucleus use members of the superfamily of importin $\beta$-like receptors (for review, see Fried and Kutay 2003). Export by these receptors requires the small GTPase Ran (for review, see Fried and Kutay 2003). 
Many RNAs, including tRNAs and snRNAs, are transported by this mechanism (Cullen 2003). In contrast, export of most poly $(\mathrm{A})^{+}$mRNAs does not rely on the direct action of Ran nor are importin $\beta$-like receptors utilized (Stutz and Izaurralde 2003; Erkmann and Kutay 2004). The factors required for poly $(\mathrm{A})^{+}$mRNA export are conserved between yeast and humans and include the export receptor Nxf1/ TAP (Mex67 in yeast) (Segref et al. 1997; Gruter et al. 1998). Both yeast Mex67p and Drosophila Nxf1 are essential for mRNA export (Segref et al. 1997; Herold et al. 2001). Like other transport receptors, TAP is proposed to translocate through nuclear pore complexes (NPCs) via interactions with NPC components (Katahira et al. 1999; Bachi et al. 2000). The recruitment of TAP to NPCs requires its heterodimerization with a small protein called p15 (Mtr2 in yeast) (Katahira et al. 1999; Fribourg et al. 2001), which enhances its affinity for nucleoporins (Levesque et al. 2001; Wiegand et al. 2002) and provides a second nucleoporin binding site in the heterodimer (Braun et al. 2002).

TAP was initially identified as the export receptor for unspliced type D retroviral RNAs (Gruter et al. 1998), which associate with TAP through a sequence-specific interaction between TAP and the constitutive transport element (CTE) in the RNA (Gruter et al. 1998; Braun et al. 1999; Kang and Cullen 1999). In contrast, TAP-mediated export of cellular poly $(\mathrm{A})^{+}$mRNAs involves its indirect recruitment to mRNAs by mRNA export adapter proteins such as Aly/REF (Yralp in yeast) (Strasser and Hurt 2000; Stutz et al. 2000; Zhou et al. 2000; Rodrigues et al. 2001). Given that Aly/REF is not essential for mRNA export (Gatfield and Izaurralde 2002; Longman et al. 2003) and that other RNA binding proteins have been shown to interact with TAP (Huang et al. 2003), it is likely that Aly/REF is only one of a number of adapter proteins for TAP.

Several different mechanisms for the recruitment of mRNA export adapters to mRNAs have been described. One way that Aly/REF associates with mRNAs is by a splicing-dependent mechanism as part of a complex of proteins, the exon junction complex (EJC), that is deposited on spliced mRNAs 20-24 nt upstream of exon-exon junctions (Kataoka et al. 2000, 2001; Le Hir et al. 2000, 2001a,b). In Xenopus oocytes, some mRNAs spliced in vivo are more efficiently exported than the same mRNA synthesized from a cDNA template (Luo and Reed 1999). Additionally, certain mRNAs containing shortened $5^{\prime}$ exons, which are no longer capable of accommodating the EJC, exhibit diminished export capacity (Le Hir et al. 2001b). These observations are consistent with the EJC being important for the recruitment of the export machinery. Despite these findings, however, it has been shown that the EJC is not essential for mRNA export in vivo (Gatfield and Izaurralde 2002), suggesting that spliced mRNAs are able to access the export machinery by additional mechanisms. Export adapters can also be recruited to mRNAs cotranscriptionally, independently of splicing, by way of the transcription/export or TREX complex that associates with pre-mRNAs during transcription elongation (Lei et al. 2001; Strasser et al. 2002; Zenklusen et al. 2002).

Very recently, Aly/REF has been shown to associate with RNAs by a process that is not coupled to splicing or transcription (Masuyama et al. 2004). In this and a previous study, it was demonstrated that unstructured RNA itself can support export factor recruitment and hence serves as an mRNA export identity element (Ohno et al. 2002; Masuyama et al. 2004). None of these mechanisms are mutually exclusive, and it is not clear which mechanism for mRNA export adapter recruitment predominates in the cell.

Studies of the steady-state localization of replication-dependent histone mRNAs in mammalian tissue culture cells suggested that the histone mRNA 3 ' end is necessary for the accumulation of histone mRNAs in the cytoplasm (Eckner et al. 1991; Williams et al. 1994) and that U7 snRNP-mediated $3^{\prime}$ end formation facilitates export (Eckner et al. 1991). In addition, there is substantial evidence suggesting that replication-dependent histone mRNAs contain specific transport elements in the protein coding region capable of redistributing a heterologous mRNA to the cytoplasm (Huang and Carmichael 1997). It has been demonstrated that these transport elements work by recruiting export adaptors to mRNAs. Steitz and coworkers have shown that the splicing factors $9 \mathrm{G} 8$ and SRp20 can be cross-linked to histone mRNA transport elements (Huang and Steitz 2001) and that 9G8 interacts with the mRNA export receptor TAP (Huang et al. 2003). These observations, and work performed by others (Braun et al. 1999; Rodrigues et al. 2001; Huang et al. 2003), suggest that TAP mediates the export of replication-dependent histone mRNAs from the nucleus.

We have extended these studies and have obtained additional evidence that TAP mediates the export of replicationdependent histone mRNAs in several experimental systems. We show here that TAP is required for histone mRNA export both in Xenopus oocytes and in cultured Drosophila cells. We have also performed a systematic analysis of the sequence determinants needed for histone mRNA export in Xenopus oocytes. Our data demonstrate that the stem-loop sequence at the $3^{\prime}$ end is not a major determinant of histone mRNA export rate in this system. Rather, the length of the region upstream of the stem-loop, but not the sequence of this region, is most important for efficient export. We additionally show that histone pre-mRNA processing is not obligatorily coupled to mRNA export in Xenopus oocytes.

\section{RESULTS}

Maturation of replication-dependent histone pre-mRNAs requires only a single processing step, endonucleolytic cleavage to form the mRNA $3^{\prime}$ end, a property that makes these mRNAs unique among all other eukaryotic messenger RNAs. The replication-dependent histone gene (mouse $\mathrm{H} 2 \mathrm{a}-614)$ used in this study is one of 12 nonallelic mouse 
H2a genes (see Marzluff et al. 2002 for a more detailed description). Since specific nuclear transport elements have previously been identified in the mouse H2a-614 mRNA (Huang and Carmichael 1997), we chose this mRNA as a model substrate for examining histone mRNA export. The Xenopus ortholog of human SLBP, xSLBP1, is required for cleavage of Xenopus histone pre-mRNAs and supports efficient cleavage of the mouse H2a-614 pre-mRNA when injected either as a precursor or expressed from an injected gene containing the mouse promoter (Williams et al. 1994; Ingledue et al. 2000). Note that unlike mammals, Xenopus oocytes contain two SLBPs. xSLBP2 is involved in cytoplasmic translational silencing of histone mRNAs during oogenesis (Wang et al. 1999; Sanchez and Marzluff 2002).

Throughout this study, only replication-dependent histone mRNAs were used and for brevity these will be referred to as histone mRNAs. When replication-independent histone mRNAs are discussed, they will be referred to explicitly. Using either histone pre-mRNAs, which are cleaved to yield the mature mRNA in the oocyte (Ingledue et al. 2000), or mature mRNAs as substrates, we have analyzed the export of histone mRNAs bearing either sequence deletions or substitutions, targeting both the coding region and conserved stem-loop sequence. The constructs used are schematized in Figure 1. The control RNAs, which were injected together with the test RNAs, were the CTE RNA, an export substrate for TAP, and U6 $\Delta$ ss snRNA, which remains in the nucleus and serves as a control for nuclear integrity and accurate injection/dissection. Following injection of the mixture of ${ }^{32} \mathrm{P}$-labeled RNAs into the nucleus, oocytes were manually dissected into nuclear and cytoplasmic fractions. Relative rates of export were assessed by comparing the distribution of the injected RNAs between the nuclear and cytoplasmic fractions at different times post-injection.

\section{The 3' end of histone mRNAs makes only a small contribution to histone mRNA export}

To determine whether SLBP association with histone mRNAs is essential for mRNA nuclear export, we compared the export rate of an mRNA ending with a mutated stemloop sequence (H2a $\Delta 297 \mathrm{rs}$ mRNA) to which SLBP cannot bind with the same mRNA ending with a wild-type stemloop sequence (H2a $\Delta 297$ wt mRNA) (Wang et al. 1999). These mRNAs are $221 \mathrm{nt}$ long and lack the first $297 \mathrm{nt}$ of the mouse H2a-614 mRNA, including the 9G8 binding site. One hour post-injection, $38 \%$ and $34 \%$ of the $\mathrm{H} 2 \mathrm{a} \Delta 297 \mathrm{wt}$ and rs mRNAs, respectively, were cytoplasmic (Fig. 2A, cf. lanes 1-3 and 7-9), while $3 \mathrm{~h}$ later the vast majority of both RNAs was present in the cytoplasm (Fig. 2A, lanes 4-6 and 10-12).

As a second approach toward assessing whether SLBP plays a role in histone mRNA export, we injected an excess of a 30-nt-long unlabeled RNA containing either the wildtype stem-loop sequence $\left(\mathrm{SL}_{\mathrm{WT}}\right)$ or the reverse stem-loop

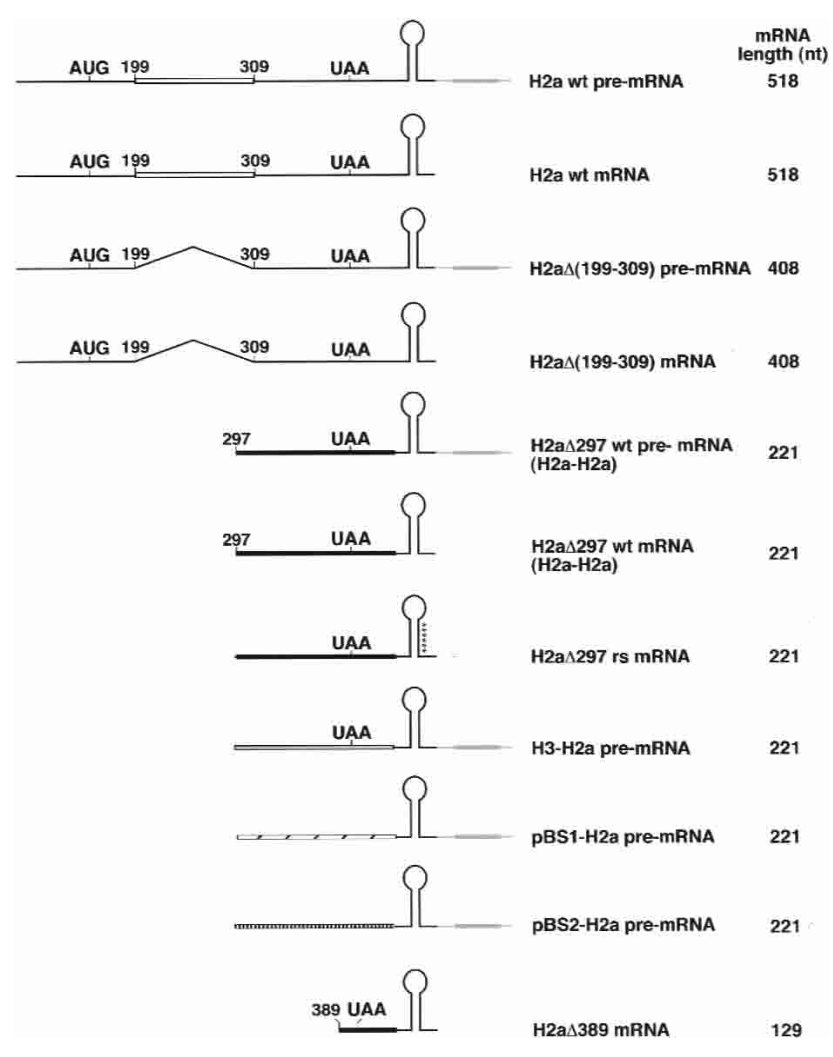

FIGURE 1. Schematic representation of mouse H2a-614 constructs used for oocyte injection experiments. The full-length mouse histone H2a-614 pre-mRNA is shown in the first line. The positions of the start (AUG) and stop (UAA) codons are indicated. The histone $\mathrm{H} 2 \mathrm{a}$ mRNA transport element (Huang and Carmichael 1997) is represented by an open box and the U7 binding site downstream of the stem-loop is indicated by a gray box. The gray line represents the part of the pre-mRNA that is removed during $3^{\prime}$ end formation. The $\mathrm{H} 2 \mathrm{a} \Delta 297$ or H2a-H2a construct is shown in the fifth line. The region upstream of the stem-loop in this construct highlighted with a black box indicates the 190-nt-long fragment that was substituted by $\mathrm{H} 3-614$ or pBlueScript sequence in the $\mathrm{H} 3-\mathrm{H} 2 \mathrm{a}$ or pBS1-H2a and pBS2-H2a constructs, respectively. The dark gray, diagonal hatched or vertical hatched boxes indicate the H3-614, and arbitrarily selected pBlueScript fragments inserted into the $\mathrm{H} 2 \mathrm{a} \Delta 297$ construct. The asterisks in the $\mathrm{H} 2 \mathrm{a} \Delta 297 \mathrm{rs}$ mRNA construct represent the reversal of the sequence in the stem region. The numbers above each construct indicate the nucleotide position relative to the transcription start site. The names and length of the mRNA formed from each construct is shown on the right.

mutation $\left(\mathrm{SL}_{\mathrm{RS}}\right)$, together with the ${ }^{32} \mathrm{P}$-labeled substrate RNAs. The $\mathrm{SL}_{\mathrm{WT}}$ competitor RNA completely blocks cleavage of the pre-mRNA in this system, demonstrating that it effectively sequesters the SLBP in the oocyte (data not shown). Consistent with the results of our rate experiment, the $\mathrm{SL}_{\mathrm{WT}}$ competitor RNA slightly reduced the rate of ${ }^{32} \mathrm{P}$ $\mathrm{H} 2 \mathrm{a} \Delta 297$ wt mRNA export while the $\mathrm{SL}_{\mathrm{RS}}$ competitor had no inhibitory effect on export (cf. lanes 1-3 of Fig. 2A with lanes 1-3 and 7-9 of Fig. 2B). Taken together, these observations suggest that the wild-type stem-loop sequence and/ or SLBP associated with the $3^{\prime}$ end contributes minimally to export. 


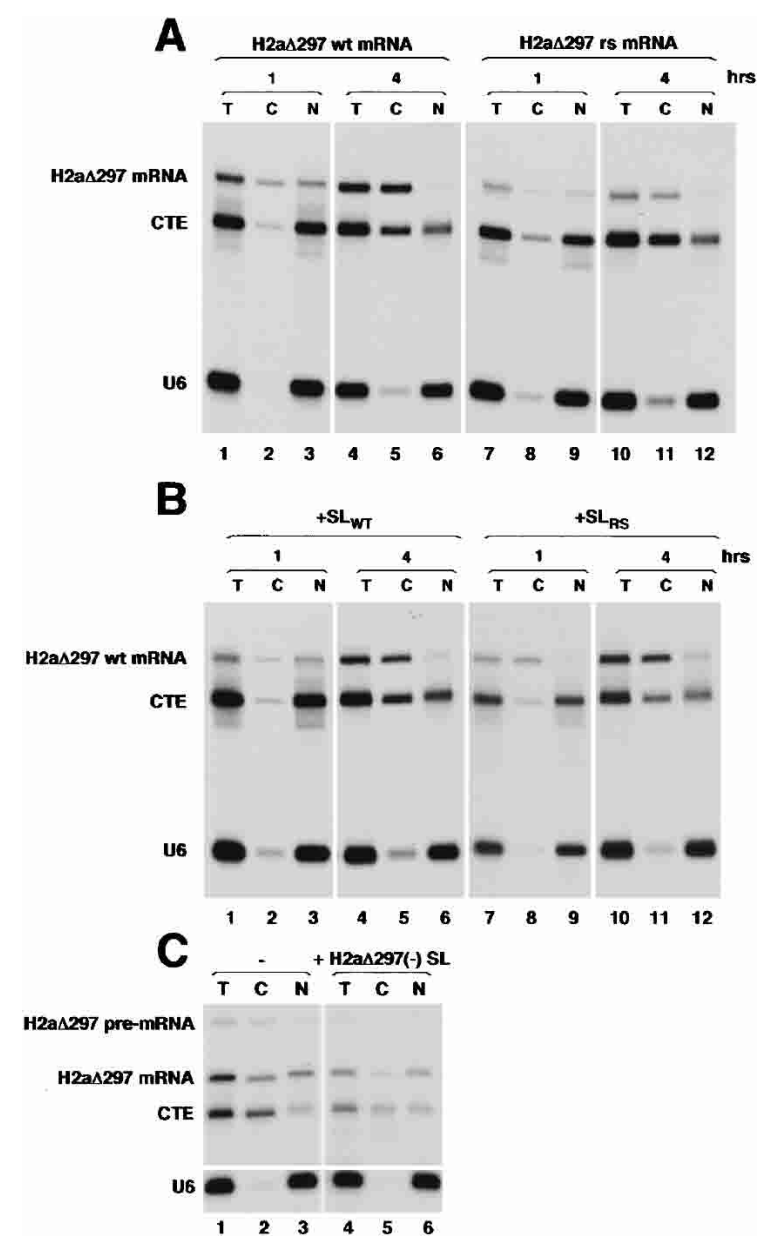

FIGURE 2. The histone mRNA stem-loop does not contribute significantly to histone mRNA export in Xenopus oocytes. (A) Histone mRNAs ending with wild-type or reversed-stem sequences have similar rates of export. The $\mathrm{H} 2 \mathrm{a} \Delta 297 \mathrm{mRNA}$ ending with either the wildtype (H2a $\Delta 297$ wt mRNA, lanes 1-6) or reverse (H2a $\Delta 297$ rs mRNA, lanes 7-12) stem-loop sequence was coinjected into the nuclei of oocytes with CTE RNA and U6 $\Delta$ ss snRNA. Oocytes were dissected after either a 1-h (lanes 1-3,7-9) or 4-h (lanes 4-6,10-12) incubation at $18^{\circ} \mathrm{C}$. (B) Coinjection of excess stem-loop RNA does not interfere with histone mRNA export. The $\mathrm{H} 2 \mathrm{a} \Delta 297$ wt mRNA, CTE RNA, and U6 $\Delta$ ss snRNA were injected into oocyte nuclei in the presence of 1 pmol/oocyte of a 30-nt-long RNA corresponding to the wild-type stem-loop sequence $\left(\mathrm{SL}_{\mathrm{WT}}\right.$, lanes 1-6) or the reverse stem-loop sequence $\left(\mathrm{SL}_{\mathrm{RS}}\right.$, lanes 7-12). (C) Histone mRNA export can be inhibited by a 190-nt-long fragment of the mouse H2a-614 mRNA lacking the $3^{\prime}$ stem-loop sequence. Radiolabeled $\mathrm{H} 2 \mathrm{a} \Delta 297$ pre-mRNA, CTE RNA, and U6 $\Delta$ ss snRNA were injected into oocyte nuclei either in the presence (lanes 4-6) or absence (lanes 1-3) of 0.5 pmol/oocyte of unlabeled $\mathrm{H} 2 \mathrm{a} \Delta 297(-)$ SL RNA. Oocytes were dissected after incubation for $3 \mathrm{~h}$ at $18^{\circ} \mathrm{C}$. One oocyte-equivalent of RNA prepared from the nuclear and cytoplasmic fractions was resolved on an $8 \%$ acrylamide/7 $\mathrm{M}$ urea gel. The gels were dried and quantification was performed using a STORM PhosphorImager and ImageQuant software. (T) Total RNA from one oocyte; (C) cytoplasmic RNA from one oocyte; (N) nuclear RNA from one oocyte. The migration of the pre-mRNA, mRNA, CTE RNA, and U6 $\Delta$ ss snRNA is indicated to the left of the gel.

Since the $3^{\prime}$ end of the histone mRNA is not essential for export, it follows that the sequences responsible for histone mRNA export would be located in the body of the mRNA. To test this hypothesis, an RNA competitor (H2a $\Delta 297(-) S L)$ corresponding to the $190 \mathrm{nt}$ upstream of the histone mRNA stem-loop was synthesized and tested for the ability to inhibit the export of the ${ }^{32} \mathrm{P}-\mathrm{H} 2 \mathrm{a} \Delta 297$ mRNA. In this particular experiment, the ${ }^{32} \mathrm{P}-\mathrm{H} 2 \mathrm{a} \Delta 297$ mRNA was produced from an injected pre-mRNA. When the H2a $\Delta 297(-) S L$ RNA was coinjected with the ${ }^{32} \mathrm{P}-\mathrm{H} 2 \mathrm{a} \Delta 297$ pre-mRNA, the amount of the ${ }^{32} \mathrm{P}-\mathrm{H} 2 \mathrm{a} \Delta 297$ mRNA exported was reduced significantly (Fig. 2C). Strikingly, the H2a $\Delta 297(-)$ SL RNA also inhibited the export of the ${ }^{32} \mathrm{P}$-CTE RNA by approximately the same amount (Fig. 2C). These data demonstrate that an RNA corresponding to the region upstream of the stem-loop is capable of titrating out the factor(s) needed for histone mRNA export. Together our observations suggest that the primary binding site in histone mRNAs for export factors is upstream of the $3^{\prime}$ end of the mRNA.

\section{Processing of histone pre-mRNAs does not enhance mRNA export in Xenopus oocytes}

It has been previously suggested that the process of histone pre-mRNA maturation is coupled to export (Eckner et al. 1991). In this study (Eckner et al. 1991), the steady-state distribution of mRNAs in transfected mammalian cells was examined and hence did not measure export directly. To determine whether processing the histone pre-mRNA has direct consequences on mRNA export, we compared the export rate of the full-length mouse H2a-614 mRNA (H2a wt mRNA) to that of the same RNA produced in Xenopus oocytes from the injected pre-mRNA (H2a wt pre-mRNA).

Within $1 \mathrm{~h}$ after injection of the H2a-614 pre-mRNA, $90 \%$ of it was processed, and $~ 50 \%$ of the processed mRNA was transported to the cytoplasm (Fig. 3A, lanes 4-6). Note that a fraction of the pre-mRNA that was not processed was also exported (Fig. 3A). After a 3-h incubation period, 95\% of the mature mRNA was cytoplasmic (Fig. 3A, lanes 1012). The H2a wt mRNA ending at the cleavage site was exported slightly faster than the message produced from the pre-mRNA, with $64 \%$ of the $\mathrm{H} 2 \mathrm{a}$ wt mRNA present in the cytoplasm 1-h post-injection (Fig. 3B, lanes 4-6). We have obtained similar results using the $\mathrm{H} 2 \mathrm{a} \Delta 297$ pre-mRNA and mRNA as substrates (data not shown). These results suggest that in Xenopus oocytes, maturation of histone pre-mRNAs is not a prerequisite for the recruitment of the export machinery to the mature mRNA.

\section{Histone mRNA export is not dictated by one specific transport element}

Huang and Carmichael have shown that a sequence in the coding region of the mouse H2a-614 mRNA can substitute for the RRE to promote export of an unspliced RNA (Huang and Carmichael 1997). To determine if this element 

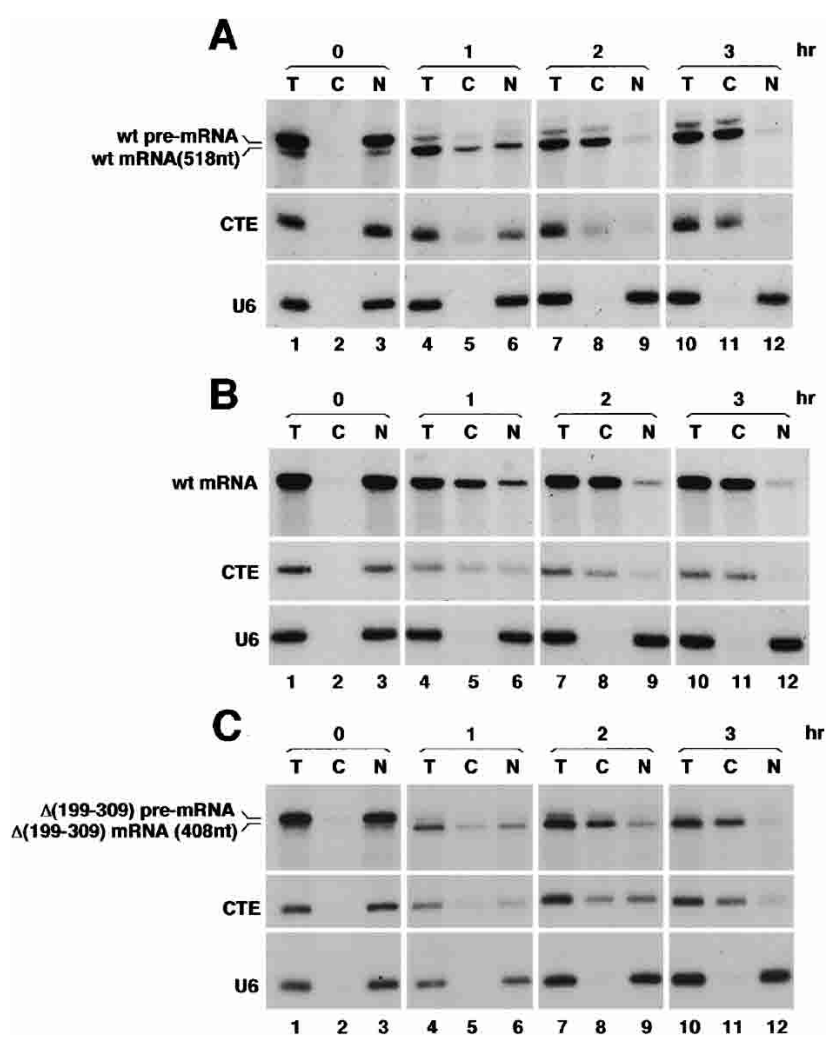

FIGURE 3. Pre-mRNA processing does not enhance histone mRNA export. $(A, B)$ A mixture of radiolabeled RNAs containing the $\mathrm{H} 2 \mathrm{a}$ wt pre-mRNA $(A)$ or H2a wt mRNA $(B)$ were injected into the nuclei of Xenopus oocytes along with CTE RNA and U6 $\Delta$ ss snRNA. Oocytes were incubated at $18^{\circ} \mathrm{C}$ and dissected at the indicated times. All samples were subsequently processed as described in Figure 2. $(C)$ The histone mRNA transport element is not essential for the export of histone mRNAs produced by pre-mRNA processing in oocytes. $\mathrm{H} 2 \mathrm{a} \Delta$ (199-309) pre-mRNA was injected into the nuclei of Xenopus oocytes along with CTE RNA and U6 $\Delta$ ss snRNA. Oocytes were incubated at $18^{\circ} \mathrm{C}$ and dissected at the indicated times. (T) total RNA from one oocyte; (C) cytoplasmic RNA of one oocyte; (N) nuclear RNA of one oocyte. The migration of the pre-mRNA, mRNA, CTE RNA, and $\mathrm{U} 6 \Delta$ ss snRNA is indicated to the left of the gel.

was essential for histone mRNA export, we deleted the 110nt region containing the transport element $(\mathrm{H} 2 \mathrm{a} \Delta(199-$ 309) mRNA) and compared the export of this mRNA and the wild-type histone mRNA. In Xenopus oocytes, both the H2a wt and $\Delta(199-309)$ pre-mRNAs were efficiently processed and the resulting mRNAs were exported at similar rates (Fig. 3A,C, lanes 4-12). The $\mathrm{H} 2 \mathrm{a} \Delta(199-309)$ mRNA demonstrated a slight lag in export (65\% cytoplasmic compared to $83 \%$ cytoplasmic 2-h post-injection; Fig. 3A,C, lanes 7-9). However, after a $3-\mathrm{h}$ incubation period (lanes 10-12), approximately the same amounts of the H2a wt and $\Delta(199-309)$ mRNAs were cytoplasmic. These results therefore indicate that, as proposed by others (Huang and Steitz 2001), histone mRNAs contain multiple export adapter binding sites, including the element initially identified by Huang and Carmichael (Huang and Carmichael 1997; Huang and Steitz 2001).
Because pre-mRNAs were used as substrates in our initial analysis of the histone mRNA transport element, we could not rule out the possibility that deleting the 9G8 binding site had only a small effect on export because 9G8, like other mRNA export adapter proteins, might normally be recruited to histone mRNAs cotranscriptionally. To address this possibility, we injected plasmid DNA containing the H2a wt or $\Delta$ (199-309) gene into oocyte nuclei together with radiolabeled U6 snRNA as an injection/dissection control and monitored the accumulation of the mRNAs in the cytoplasm using an S1 nuclease protection assay. There is a substantial lag after injection of the DNA before the gene is transcribed, and 6-8 $\mathrm{h}$ after injection of the DNA represents a period of rapid RNA accumulation. Eight hours following nuclear injection of the H2a wt and $\mathrm{H} 2 \mathrm{a} \Delta$ (199-309) constructs, both mRNAs produced from the injected plasmids accumulated in the cytoplasm to a similar extent, with $\sim 80 \%$ of each present in the cytoplasm (Fig. $4 \mathrm{~A}$, upper panel). Thus, these observations suggest that, as for mRNAs cleaved from injected pre-mRNAs, the export of a histone mRNA produced from an injected gene in Xenopus oocytes likely involves the usage of multiple transport sequences.

To determine whether the observations made in Xenopus oocytes were general or system specific, we used an mRNA FISH assay to characterize the localization of the H2a wt and $\Delta(199-309)$ mRNAs produced in HeLa cells after transient transfection. Because the mouse and human H2a-614 mRNAs share sequence similarity, a probe against the mouse H2a-614 mRNA cross-hybridized weakly with the endogenous human H2a-614 mRNA. The signal in cells transfected with the mouse H2a-614 plasmid was significantly higher, thus making it possible to differentiate between transfected and untransfected cells (Fig. 4B). Our mRNA FISH analysis of the mouse H2a-614 mRNAs revealed that both the H2a wt and $\Delta(199-309)$ mRNAs were exclusively cytoplasmic under steady-state conditions (Fig. $4 \mathrm{C}$, upper panels). Taken together, our data strongly suggest that histone mRNAs contain multiple transport elements.

To determine whether there is a specific sequence in the histone mRNA downstream of the 9G8 binding site required for efficient mRNA export, we replaced the sequence between this region and the stem-loop in the $\mathrm{H} 2 \mathrm{a} \Delta 297$ mRNA with the corresponding sequence from another replication-dependent mouse histone gene, H3-614 (H3-H2a), or two different identically sized fragments from the plasmid pBlueScript (pBS1-H2a and pBS2-H2a). If there is a transport element specific to histone mRNAs, we predicted that the H3-H2a hybrid would have a similar export capacity to the H2a $\Delta 297$ mRNA construct, while those containing vector sequences would be defective in export. Thirty minutes post-injection of Xenopus oocyte nuclei, $\sim 65 \%$ of the $\mathrm{H} 2 \mathrm{a}-\mathrm{H} 2 \mathrm{a}$ mRNA was present in the cytoplasm (Fig. 5A, lanes 1-3). A similar distribution of the H3-H2a mRNA between the nucleus and cytoplasm was seen at this time and a similar amount of both precursors was exported to 


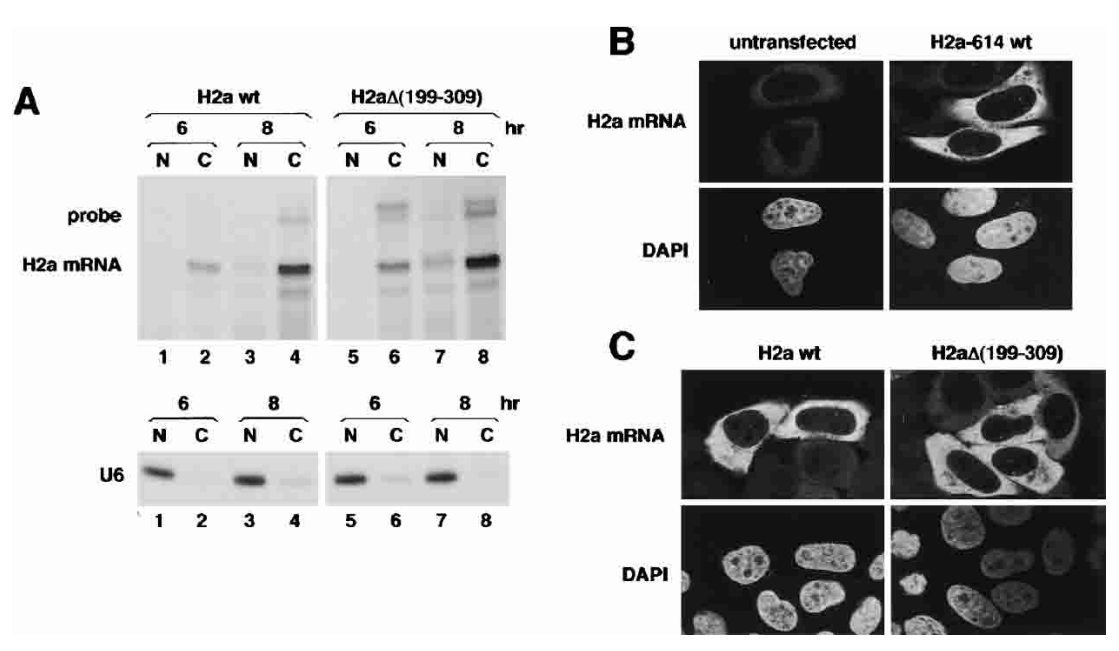

FIGURE 4. The $9 \mathrm{G} 8$ binding site in the mouse H2a-614 mRNA is not essential for export in systems where the mRNA is produced by transcription in vivo. (A) H2a-614 wt and $\mathrm{H} 2 \mathrm{a} \Delta$ (199309) mRNAs transcribed from an injected gene do not require the 9G8 binding site for their export in frog oocytes. Oocytes were injected in the nucleus with $750 \mathrm{pg}$ of plasmid DNA containing the wild-type mouse $\mathrm{H} 2 \mathrm{a}-614$ gene (lanes 1-4) or the H2a-614 gene deleted for the region between nt 199 and 309 (lanes 5-8) along with radiolabeled U6 $\Delta$ ss snRNA and blue dextran. Following either a 6 - or 8 -h incubation period at $18^{\circ} \mathrm{C}$, the oocytes were dissected. One oocyte equivalent of RNA from the nuclear and cytoplasmic fractions was subject to an S1 nuclease protection assay (top panel) as described (Ingledue et al. 2000; Dominski et al. 2002a) or resolved on a denaturing gel to visualize the radiolabeled U6 $\Delta$ ss snRNA. The migration of the undigested probe and the probe fragment protected by both the H2a wt and $\Delta(199-309)$ mRNAs is indicated to the left of the gel. (B) Detection of overexpressed mouse H2a-614 by mRNA fluorescence in situ hybridization. mRNA FISH of untransfected HeLa cells was carried out using a probe targeting the sequence between the PstI site and stem-loop sequence in the mouse H2a-614 mRNA. The intensity of the signal arising from cross-hybridization of the human H2a-614 mRNA with the mouse probe in untransfected cells (left panels) was compared with that of cells transfected with the mouse H2a-614 gene (right panels). The signal produced by the mRNA FISH is shown in the upper panels. Cells were counterstained with DAPI to visualize nuclei (lower panels). (C) The H2a-614 wt and $\mathrm{H} 2 \mathrm{a} \Delta(199-309)$ mRNAs are exclusively cytoplasmic in HeLa cells. HeLa cells were transiently transfected for $24 \mathrm{~h}$ with the wild-type mouse H2a-614 gene (left) or the $\mathrm{H} 2 \mathrm{a} \Delta$ (199-309) (right) construct. The H2a mRNA FISH and DAPI staining are shown in the upper and lower panels, respectively.

the cytoplasm, $15 \%$ and $11 \%$, respectively (Fig. $5 \mathrm{~A}$, lanes 1-3 and 7-9). Strikingly, export of the pBS1-H2a mRNA was more efficient than the export of the two chimeras containing histone sequence, with $97 \%$ of this mRNA present in the cytoplasm after $1 \mathrm{~h}$ (Fig. 5B, lanes 4-6). These observations suggest that histone mRNAs do not contain a specific element in the region upstream of the stem-loop sequence, which is essential for export.

Interestingly, the pBS1-H2a precursor was either processed poorly compared to the $\mathrm{H} 2 \mathrm{a}-\mathrm{H} 2 \mathrm{a}$ and $\mathrm{H} 3-\mathrm{H} 2$ a premRNA constructs or was exported more rapidly, as a substantial amount (over 70\%) of this pre-mRNA was cytoplasmic after the 1-h incubation period (Fig. 5B, lanes 4-6). A second chimeric pre-mRNA containing a different 190nt-long piece of pBlueScript fused to the mouse H2a-614 3' end (pBS2-H2a) showed a similar rapid accumulation in the cytoplasm (Fig. 5B, lanes 7-9). The pBS2-H2a premRNA, however, was cleaved somewhat better than the pBS1-H2a pre-mRNA (Fig. 5B, cf. lanes 4 and 10).

\section{Histone mRNA export is dependent on TAP in $X$. laevis oocytes}

To confirm and extend previous observations (Braun et al. 1999; Huang et al. 2003) that implicated TAP in histone mRNA export, we performed a competition experiment using as competitors either a wild-type (wt) or mutated (mut) CTE that is incapable of binding TAP (Kang and Cullen 1999). The wt CTE competed the export of the ${ }^{32} \mathrm{P}$ CTE RNA and the ${ }^{32} \mathrm{P}-\mathrm{H} 2 \mathrm{a} \Delta 297$ histone mRNA (Fig. 6, lanes 1-6). In contrast, the mut CTE did not inhibit the export of the ${ }^{32} \mathrm{P}-\mathrm{H} 2 \mathrm{a} \Delta 297$ mRNA or ${ }^{32} \mathrm{P}-\mathrm{CTE}$ RNA (Fig. 6, lanes 7-9), demonstrating that the export block induced by the wt CTE was specific. These results provide further evidence that TAP is required for histone mRNA export in Xenopus oocytes.

\section{Shortening the histone mRNA reduces its rate of export}

It has been reported that some RNAs exported by TAP (not containing the CTE), which are efficiently exported in frog oocytes, are exported at a reduced rate when shortened (Rodrigues et al. 2001). To determine whether histone mRNAs share this property with other messenger RNAs, we tested whether shortening histone mRNAs influenced their rate of export. A series of three mRNAs consisting of the $\mathrm{H} 2 \mathrm{a} \Delta(199-309)$, the $\mathrm{H} 2 \mathrm{a} \Delta 297$ mRNA, and H2a $\Delta 389$ mRNA was used for this analysis. The sizes of these mRNAs are 408, 221, and 129 nt, respectively. The 408-nt-long H2a $\Delta(199-309)$ mRNA was efficiently transported to the cytoplasm with $\sim 80 \%$ and $90 \%$ of the mRNA present in the cytoplasm 1- and 2-h post-injection, respectively (Fig. 7A, lanes 1-3; data not shown). Approximately $70 \%$ of the $\Delta 297 \mathrm{mRNA}$ was exported to the cytoplasm after $1 \mathrm{~h}$ following injection (Fig. 7A, lanes 4-6). The H2a $\Delta 389$ mRNA exhibited a much slower rate of accumulation in the cytoplasm, with only $27 \%$ of this mRNA exported to the cytoplasm in $1 \mathrm{~h}$ (Fig. 7A, lanes 7-9), and $36 \%$ in $2 \mathrm{~h}$ (data not shown). These observations therefore suggest that RNA length makes an important contribution to histone mRNA export rate.

Very recently, it has been shown that export of mRNAs $<300 \mathrm{nt}$ long is rerouted from the TAP pathway to the CRM1 pathway, which is normally used by snRNAs (Masuyama et al. 2004). Because the H2a $\Delta 389$ mRNA is only 


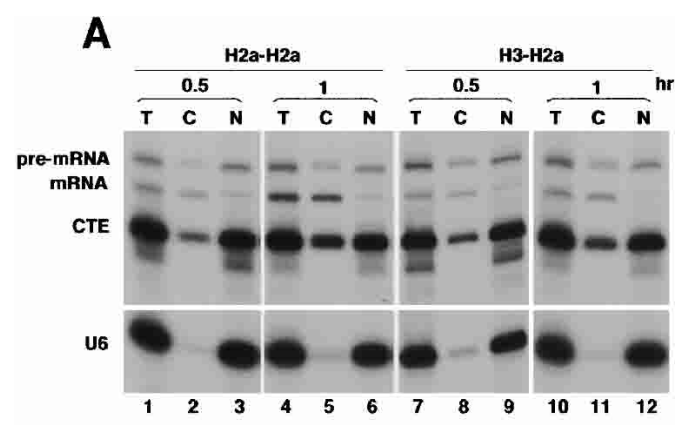

B

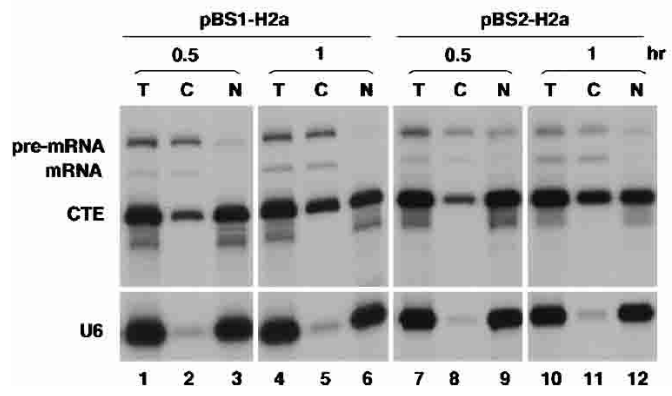

FIGURE 5. The identity of the sequence upstream of the stem-loop is not a critical determinant for histone mRNA export. Chimeric histone precursors the size of the $\mathrm{H} 2 \mathrm{a} \Delta 297$ construct (A, lanes 1-6) containing either histone $\mathrm{H} 3$ sequence $(A$, lanes $7-12)$ or different pBlueScript sequences upstream of the mouse H2a-614 stem-loop ( $B$; see Fig. 1) were synthesized and injected into oocyte nuclei as part of a mixture containing CTE RNA and U6 $\Delta$ ss snRNA. Oocytes were incubated for either $30 \mathrm{~min}(A, B$, lanes $1-3,7-9)$ or $1 \mathrm{~h}(A, B$, lanes 4-6,10-12) at room temperature and then dissected into nuclear and cytoplasmic fractions. The samples were then processed as described in Figure 2. It should be pointed out that since this experiment was carried out at room temperature, rates of export observed in this experiment cannot be directly compared with those obtained in other experiments. (T) total RNA from one oocyte; (C) cytoplasmic RNA of one oocyte; $(\mathrm{N})$ nuclear RNA of one oocyte. The migration of the pre-mRNA, mRNA, CTE RNA, and U6 $\Delta$ ss snRNA is indicated to the left of the gel.

$129 \mathrm{nt}$ long, it was important to test whether this RNA was still exported by TAP. To do so, we attempted to inhibit the export of the ${ }^{32} \mathrm{P}-\mathrm{H} 2 \mathrm{a} \Delta 389$ mRNA by competition with unlabeled CTE RNA. A mixture containing ${ }^{32} \mathrm{P}$-labeled CTE RNA, U6 $\Delta$ ss snRNA, and the $\mathrm{H} 2 \mathrm{a} \Delta 389$ pre-mRNA was injected into oocyte nuclei in the absence or presence of unlabeled CTE RNA as competitor. Two hours post-injection, the oocytes were dissected and the fraction of the mRNA present in the cytoplasm was determined. In the absence of excess CTE RNA, $60 \%$ of the ${ }^{32} \mathrm{P}-\mathrm{H} 2 \mathrm{a} \Delta 389$ mRNA was cytoplasmic (Fig. 7B, lanes 1-3) while coinjection of excess CTE RNA inhibited the export of ${ }^{32} \mathrm{P}$ H2a $\Delta 389$ mRNA by $\sim 20 \%$ (lanes 4-6). These results demonstrate that TAP at least contributes to the export of the 129-nt H2a $\Delta 389$ mRNA. Taken together, based on our observations using these shortened histone mRNAs, one can conclude that TAP-mediated histone mRNA export is dependent on RNA length.

\section{Depletion of TAP/Nxf1 in Drosophila S2 cells blocks histone mRNA nuclear export}

Replication-dependent histone mRNAs in Drosophila contain the conserved stem-loop sequence and are cleaved by a processing machinery similar to humans (Dominski et al. 2002b, 2003; Azzouz and Schumperli 2003). To address whether histone mRNAs are exported by TAP in vivo, we used an RNAi based approach in Drosophila S2 cells. The involvement of the Drosophila homolog of TAP, Nxf1, in general poly $(\mathrm{A})^{+}$mRNA export and in the export of specific mRNAs has been established using this technique (Herold et al. 2001, 2003). The effectiveness of the Nxf1 RNAi was monitored by Western blot analysis. Samples were normalized based on cell-equivalents rather than total protein content as depletion of Nxfl has previously been shown to cause a reduction in cellular protein levels (Herold et al. 2001). Four days after transfection of a double-stranded RNA that targets Nxf1, Nxf1 levels were markedly reduced (Fig. 8A, cf. lanes 1 and 2) as has previously been reported (Herold et al. 2001). The Nxf1 antibody cross-reacts with another cellular protein (indicated with an ${ }^{\star}$ ) whose levels are not affected by Nxf1 depletion. A double-stranded control RNA against SLBP had no effect on Nxf1 levels (Fig. 8A, lane 3). To assess whether the histone mRNAs in Nxf1depleted cells were properly processed, we performed S1 nuclease mapping of the replication-dependent $\mathrm{H} 2 \mathrm{a}$ mRNA. In both control and Nxf1-depleted cells, the $3^{\prime}$ end of the H2a mRNA mapped to the same position (Fig. 8B, cf. lanes 2 and 3), demonstrating that histone mRNAs produced in cells lacking Nxf1 were correctly processed.

To determine the localization of poly $(\mathrm{A})^{+}$RNA and histone H2a mRNA in S2 cells, we used an mRNA FISH assay. Under steady-state conditions, the bulk of poly $(\mathrm{A})^{+}$mRNA is predominantly cytoplasmic (Fig. $8 \mathrm{C}$, top panels). As shown previously (Herold et al. 2001), already $1 \mathrm{~d}$ after the introduction of a double-stranded RNA against Nxfl, poly $(\mathrm{A})^{+}$mRNA accumulated in the nucleus (Fig. 8C, bot-

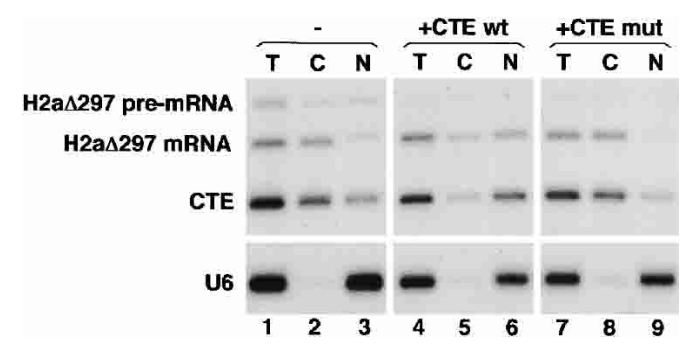

FIGURE 6. The CTE RNA inhibits histone mRNA export. Radiolabeled histone $\mathrm{H} 2 \mathrm{a} \Delta 297$ pre-mRNA, CTE RNA, and U6 $\Delta$ ss snRNA were injected into oocyte nuclei in the presence of $0.5 \mathrm{pmol} /$ oocyte of unlabeled CTE wt RNA (lanes 4-6), CTE mut RNA (lanes 7-9), or in the absence of competitor RNA (lanes 1-3). Oocytes were incubated for $3 \mathrm{~h}$ at $18^{\circ} \mathrm{C}$, dissected, and subsequently processed as in Figure 2 . (T) total RNA from one oocyte; (C) cytoplasmic RNA of one oocyte, $\mathrm{N}$; nuclear RNA of one oocyte. The migration of the pre-mRNA, mRNA, CTE RNA, and U6 $\Delta$ ss snRNA is indicated to the left of the gel. 

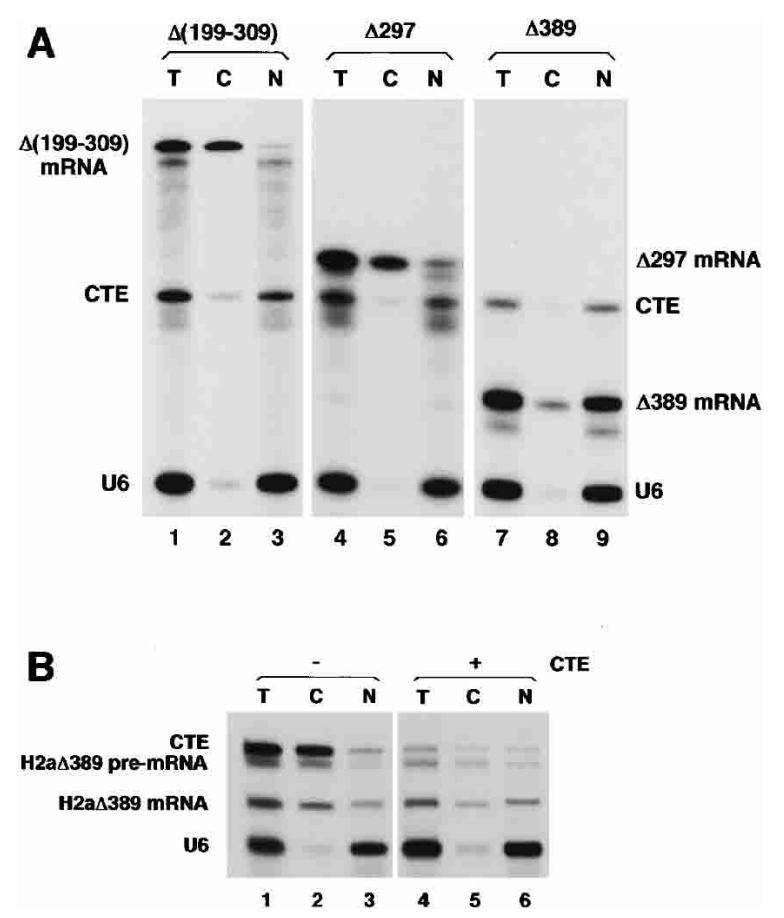

FIGURE 7. Reducing the size of histone mRNA reduces its rate of export. (A) Radiolabeled H2a $\Delta$ (199-309) (lanes 1-3), H2a $\Delta 297$ (lanes 4-6) and H2a $\Delta 389$ mRNAs (lanes 7-9) were combined with CTE RNA and U6 $\Delta$ ss snRNA and injected into oocyte nuclei. Oocytes were dissected after a 1-h incubation at $18^{\circ} \mathrm{C}$. (B) Export of the $\mathrm{H} 2 \mathrm{a} \Delta 389$ mRNA is partially inhibited by CTE RNA. H2a $\Delta 389$ pre-mRNA was coinjected with CTE RNA and U6 $\Delta$ ss snRNA into oocyte nuclei in the absence (lanes 1-3) or presence (lanes 4-6) of $0.5 \mathrm{pmol}$ of unlabeled CTE RNA. Oocytes were incubated for $2 \mathrm{~h}$ at room temperature and dissected into nuclear and cytoplasmic fractions. The samples were then processed as in Figure 2. Note that experiments in $A$ and $B$ have been performed at different temperatures resulting in different export rates of the H2a $\Delta 389$ mRNA. Additionally, it should be noted that nuclear degradation of CTE RNA caused by inhibition of CTE export has been observed by others (Pasquinelli et al. 1997). This phenomenon likely accounts for the reduction in total CTE levels in oocytes injected with unlabeled CTE RNA. (T) total RNA from one oocyte; (C) cytoplasmic RNA of one oocyte; (N) nuclear RNA of one oocyte. The migration of the mRNAs, CTE RNA, and U6 $\Delta$ ss snRNA is indicated to the left of the gel.

tom panels). Histone mRNA was detected using a digoxygenin-labeled probe against the Drosophila H2a mRNA. In the absence of Nxf1 removal, H2a mRNA was present almost exclusively in the cytoplasm (Fig. 8D, top panels) and, consistent with its expression being restricted to $S$ phase, was present in high levels only in a fraction of the cells. A probe against histone $\mathrm{H} 3$ gave a similar staining pattern to the $\mathrm{H} 2 \mathrm{a}$ probe, and the signal from the $\mathrm{H} 2 \mathrm{a}$ and $\mathrm{H} 3$ probes was eliminated by RNase treatment (data not shown). Strikingly, $1 \mathrm{~d}$ following the introduction of a dsRNA targeting Nxf1, histone mRNA could be detected in the nucleus of some of the cells (Fig. 8D, bottom panels). It should be emphasized that the nuclear accumulation of histone mRNA was observed shortly after the onset of Nxf1 depletion, indicating that this phenotype was likely to be directly related to the cellular depletion of Nxf1 and not an indirect consequence. These results are consistent with histone mRNA being transported by Nxf1 in cultured Drosophila cells.

During the time course of the RNAi, there was a substantial increase in the number of cells that displayed nuclear poly $(\mathrm{A})^{+}$and nuclear histone mRNA staining. However, the depletion of Nxf1 for $4 \mathrm{~d}$ resulted in an overall decrease in the number of cells containing histone mRNA (from almost $30 \%$ to $10 \%$; Fig. $8 \mathrm{E}$, upper panels). Because of the reported growth defect of S2 cells depleted for Nxf1 (Herold et al. 2001), we reasoned that the reduction in the number of cells expressing histone mRNA resulted from fewer cells being in $S$ phase. To address this possibility, BrdU labeling was carried out on either mock-treated cells or cells that were subject to Nxf1 RNAi for $4 \mathrm{~d}$. Consistent with the growth defect caused by depletion of Nxf1 there was an $\sim 30 \%$ reduction in the number of cells in $S$ phase under conditions where Nxf1 was removed by RNAi (Fig. $8 \mathrm{E}$, lower panels). Thus, the observed reduction in cells expressing histone mRNA was caused indirectly by a cell cycle or growth defect resulting from Nxf1 depletion.

\section{DISCUSSION}

The final step in mRNA biosynthesis is transport of the mature mRNA to the cytoplasm. The export receptor TAP/ p15 is recruited to polyadenylated mRNAs through mRNA export adapter proteins like Aly/REF/Yralp, which can associate with mRNAs during transcription, splicing, or even $3^{\prime}$ end formation. The replication-dependent histone mRNAs are the only nonpolyadenylated eukaryotic cellular mRNAs and among only a few mammalian mRNAs that do not contain introns. Maturation of histone pre-mRNAs entails only capping and endonucleolytic cleavage to form the $3^{\prime}$ end of the mRNA. Here we have shown that the replication-dependent histone mRNAs are exported by a system that requires TAP and that the length of histone mRNAs is the major determinant of their export rate.

\section{Histone pre-mRNA processing, SLBP, and nuclear export}

It has previously been suggested that the conserved stemloop sequence in histone mRNAs and authentic U7 snRNPmediated processing are necessary for efficient export (Eckner et al. 1991; Williams et al. 1994). In both reports, the steady-state localization of mRNAs produced from continuously transcribed genes in tissue culture cells was examined by cell fractionation. The impact of mutations in the stemloop structure and U7 snRNP independent 3 ' end formation on the cellular distribution of histone mRNAs was examined. Due to the nature of the experimental systems used, it could not be addressed whether the primary defect in cytoplasmic accumulation was in nuclear export. For example, the mutant mRNAs could have been unstable in 
A

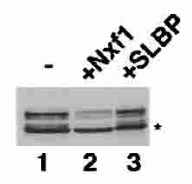

B

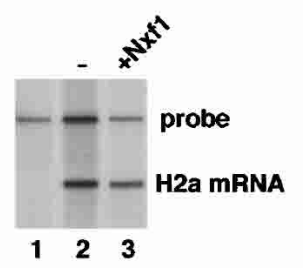

C

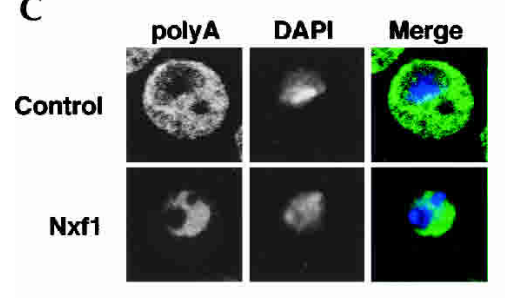

D

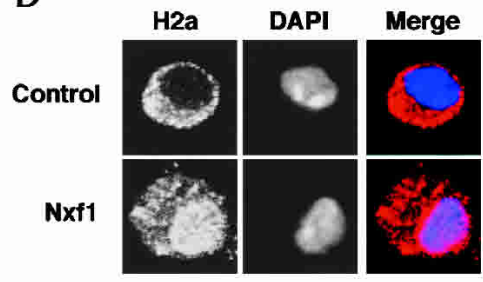

E

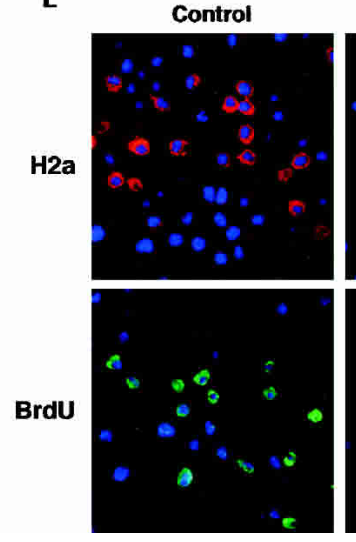

FIGURE 8. Histone mRNA export is blocked in Nxf1-depleted cells. (A) Nxf1 depletion from S2 cells by RNA interference. Extracts were prepared from either control (lane 1) or Nxf1- (lane 2) or SLBP- (lane 3) depleted S2 cells after $4 \mathrm{~d}$ of RNAi. A portion of each sample representing an equivalent number of cells was resolved on a 10\% SDS-PAGE, transferred to nitrocellulose, and probed for Nxf1. The asterisk marks a protein that cross-reacts with the Nxf1 antibody and serves as an internal loading control. (B) Histone H2a mRNAs in Drosophila cells depleted of Nxf1 end with the correct $3^{\prime}$ end. RNA prepared from either control (lane 2) or Nxf1-depleted (lane 3) cells was subject to a $3^{\prime} \mathrm{S} 1$ nuclease protection assay using a probe against the Drosophila H2a mRNA (Lanzotti et al. 2002). (Lane 1) the probe digested with S1. (C) poly (A) ${ }^{+}$ mRNAs are restricted to the nucleus when Nxf1 is not present. Control cells mock treated for $1 \mathrm{~d}$ and cells treated for $1 \mathrm{~d}$ with a double-stranded RNA against Nxf1 were processed for mRNA FISH using a biotinylated oligo(dT) probe (left panels). Detection was carried out using FITC-conjugated avidin. Cells were counterstained with DAPI (middle panels). The overlayed images of the oligo(dT) (green) and DAPI (blue) staining are shown in the third column. (D) Histone mRNAs accumulate in the nucleus when Nxf1 is depleted. Control cells mock treated for $1 \mathrm{~d}$ and cells treated for $1 \mathrm{~d}$ with a double-stranded RNA against Nxf1 were processed for mRNA FISH using a DIG-dUTP labeled histone H2a probe. Detection was carried out using a cy3 anti-DIG antibody (left panels). Cells were counterstained with DAPI (middle panels). The merged images of the histone mRNA (red) and DAPI (blue) staining are shown in the right panels. (E) Nxf1-dependent decrease in the number of cells producing histone mRNA is due to a reduction in the percentage of $S$ phase cells. Control cells mock treated for $4 \mathrm{~d}$ and cells treated for $4 \mathrm{~d}$ with a double-stranded RNA against Nxf1 were processed for mRNA FISH as above (top panels). Cells treated in an identical fashion were subsequently labeled with BrdU (lower panels). BrdU was detected using a mouse anti-BrdU antibody (Roche) and a FITCanti-mouse secondary antibody (Sigma). The BrdU is shown in green and the DAPI staining is shown in blue.

either the nucleus or the cytoplasm. Additionally, regarding the studies that addressed processing, it is possible that defects in export were due to inefficient release of mRNAs from chromatin. Thus, it remained unclear whether $3^{\prime}$ end processing or the $3^{\prime}$ end play an active role in histone mRNA export.

To directly assess whether processing of histone premRNAs influences the rate of histone mRNA export, we used Xenopus oocytes as a model system. By injection of pre-mRNAs into the oocyte nucleus, we were able to ex-

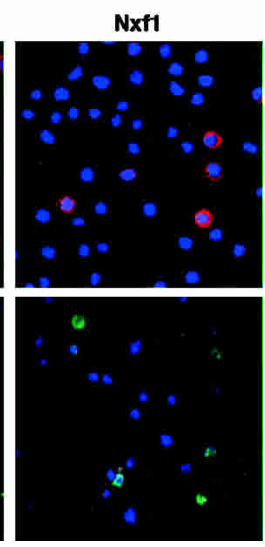

amine the nuclear export of histone mRNAs in a manner independent of their transcription. Our work shows that a histone mRNA formed from an injected pre-mRNA was not exported any faster than the corresponding mature mRNA. In fact, the injected mRNA was exported more rapidly than the mRNA made from the histone pre-mRNA. These results strongly suggest that cleavage of the pre-mRNA does not facilitate the association of the export machinery with the histone mRNA in Xenopus oocytes. Therefore, proper $3^{\prime}$ end formation might be required at a step prior to export, e.g., for release from the site of transcription.

In addition, our studies clearly show that the $3^{\prime}$ end per se is not essential for histone mRNA export in Xenopus oocytes based on two observations: Injected histone mRNAs ending in a reversed stem-loop sequence, which cannot bind SLBP, are exported with a rate similar to that of wild-type histone mRNAs, and injection of an excess of a 30-nt stem-loop RNA, which is sufficient to sequester all the SLBP in the germinal vesicle, has only a minor effect on histone mRNA export. Taken together, our data show that $3^{\prime}$ end formation and the stem-loop sequence do not directly influence histone mRNA export.

\section{Do replication-dependent histone mRNAs contain multiple transport elements?}

In addition to the histone mRNA $3^{\prime}$ end, a sequence found in the coding region of some histone mRNAs has been proposed to be involved in histone mRNA export (Huang and Carmichael 1997). A 101-nt region from the open reading frame of the mouse $\mathrm{H} 2 \mathrm{a}-614 \mathrm{mRNA}$ (the same gene used in our studies) acted as a dominant transport element (Huang and Carmichael 1997) and was sufficient to replace the RRE as an export signal. A minimal H2a transport element of $22 \mathrm{nt}$ was defined, which when multimerized, stimulated the export of a synthetic 331-nt mRNA when injected into the nucleus of frog oocytes (Huang and Steitz 2001). The same RNA carrying four copies of a mutated element was retained in the nucleus (Huang and Steitz 2001). The SR splicing factors 9G8 and SRp20 could be 
specifically cross-linked to the $\mathrm{H} 2 \mathrm{a}$ transport element and antibodies against both proteins were shown to inhibit the export of a histone transport element-containing RNA (Huang and Steitz 2001). Recently, some of the shuttling SR proteins, including 9G8, have been shown to associate with TAP (Huang et al. 2003). Interestingly, a fragment of 9G8 that can compete with REF for TAP association acts as a dominant negative inhibitor of spliced RNA export in oocytes (Huang et al. 2003).

Huang and Steitz have proposed that the efficient export of intronless mRNAs may require a "high density" of export adapter binding sites (Huang and Steitz 2001). Consistent with this hypothesis, while the 101-nt element in the mouse H2a-614 mRNA is clearly a transport element (Huang and Carmichael 1997; Huang and Steitz 2001), we find that it is not the sole sequence needed for histone mRNA export. In Xenopus oocytes, we have shown that an mRNA lacking the histone transport element was exported only slightly slower than the wild-type histone mRNA. When this mRNA was produced from an injected gene, it accumulated efficiently in the cytoplasm. Similarly, in HeLa cells, the transport element-deleted mRNA expressed by transient transfection displayed cytoplasmic localization like the wild-type mRNA. Our results therefore suggest that there are indeed other sequences in histone mRNAs in addition to the previously identified histone mRNA transport element that function as adapter protein binding sites. It is very possible that there are other 9G8 binding sites in the mouse H2a-614 mRNA and that, as suggested by others (Rodrigues et al. 2001), other adapter proteins in addition to 9G8 like Aly/ REF participate in TAP recruitment to histone mRNAs.

In an effort to determine whether there are specific histone mRNA transport elements, we found that no single sequence in the histone mRNA was necessary for its export in Xenopus oocytes. Strikingly, the sequence upstream of the $3^{\prime}$ end in the histone mRNA could be replaced by plasmid sequences without affecting the rate of export. It should be noted that neither of the consensus 9G8 binding sites (Schaal and Maniatis 1999) are present in the pieces of pBlueScript used in these experiments. These findings suggest that adapter protein recognition is somewhat sequenceindependent and that there is not a specialized sequence in histone mRNAs that mediates their export.

\section{Histone mRNAs are exported by TAP}

It has recently been shown that nuclear export of an RNA containing the mouse $\mathrm{H} 2 \mathrm{a}-614$ transport element fused to the $3^{\prime}$ UTR of the mouse H3-614 mRNA, a highly expressed histone $\mathrm{H} 3$ gene closely linked to the $\mathrm{H} 2 \mathrm{a}-614$ gene, can be stimulated twofold by coinjection of recombinant TAP (Huang et al. 2003). Additionally, the export of histone mRNAs by TAP has been indirectly implicated in other studies (Braun et al. 1999; Rodrigues et al. 2001). We provide two additional lines of evidence demonstrating that TAP mediates export of authentic histone mRNAs: (1) ex- cess CTE-containing RNA inhibits histone mRNA export in Xenopus oocytes, and (2) depletion of TAP/Nxf1 from Drosophila cultured cells results in the accumulation of processed histone mRNA in the nucleus. There are other examples of intronless mRNAs that are exported by TAP (Herold et al. 2001), but this is the first demonstration of TAP-mediated export of a nonpolyadenylated mRNA.

\section{Histone mRNA export is dependent on the length of the transcript}

While attempting to characterize the cis-sequence requirements for histone mRNA export we discovered that the length of the histone mRNA substrate contributed significantly to the RNA's export rate. Histone mRNAs of 220 nt or longer were efficiently exported. However, histone mRNAs that were further reduced in size were exported significantly more slowly. A similar observation has been made for the widely used $\beta$-globin and Fushi tarazu (Ftz) mRNAs that are less efficiently exported when reduced in size from 360 to 248 and 343 to $218 \mathrm{nt}$, respectively (Rodrigues et al. 2001). Our data are consistent with the hypothesis proposed by these authors that states that the export defect observed for shortened mRNAs is due to the loss of mRNA export adapter binding sites. Perhaps maximal mRNA export rate requires the association of a certain number of adapter molecules, and shorter mRNAs are exported inefficiently because they bind too few adaptor proteins.

Taken together our data suggest that histone mRNA export could be explained by the model that stretches of unstructured RNA can serve as an mRNA export identity element (Ohno et al. 2002). Ohno et al. (2002) have demonstrated that U1 snRNA, normally a substrate for the export receptor CRM1, could be redirected into the mRNA export pathway by the insertion of an unstructured stretch of RNA. This is potentially interesting from a mechanistic standpoint as snRNAs and histone mRNAs are among the only Pol II transcripts lacking poly(A) tails, yet these two classes of RNAs are exported along different pathways. CRM1 is recruited to snRNAs through their $5^{\prime}$ cap structure (Fischer et al. 1995; Izaurralde et al. 1995; Fornerod et al. 1997), a feature common to all Pol II transcripts. Thus, the specificity of CRM1 for only snRNAs is not obvious. However, as discussed by Mattaj and colleagues (Ohno et al. 2002), unstructured RNA might be dominant over the $5^{\prime}$ cap in terms of export machinery recruitment and it is by this mechanism that mRNAs are able to enter the TAP pathway. Important advances in understanding how CRM1 and TAP choose their transport cargoes have recently been made. Ohno and colleagues have demonstrated that RNAs shorter than $200 \mathrm{nt}$, regardless of the presence of a U1 snRNA 3' end, are exported by CRM1 rather than TAP (Masuyama et al. 2004). The trend in increased usage of the CRM1 pathway as the size of the mRNA was reduced correlated with a decreased 
association with Aly/REF and an increased association of the RNA with factors involved in U1 snRNA export.

In the case of histone mRNAs, which are typically 500$600 \mathrm{nt}$ long but lack certain features of other mRNAs, like exon-exon junctions and poly(A) tails, their export most likely occurs by a mechanism dependent on regions of unstructured RNA. In this model, histone mRNA export would be facilitated by adapter proteins that bind through multiple sites in the mRNA. We note that there is unexpected conservation of the nucleotide sequence in the coding region of replication-dependent histone mRNAs (DeBry and Marzluff 1994) consistent with selection occurring at the level of the nucleotide as well as the protein sequence. It is likely that the sequence of histone mRNAs has evolved to be optimal for coordinating histone pre-mRNA processing with rapid mRNA export (Schochetman and Perry 1972).

\section{Conclusions}

In this work we have shown that the major determinant of replication-dependent histone mRNA export rate is the length of the mRNA. We have additionally demonstrated that TAP is the export receptor for the replication-dependent histone mRNAs in vivo. Together our data support a model in which TAP is recruited to the body of the histone mRNA upstream of the 3 ' stem-loop sequence. Our observations are most consistent with the mRNA export identity element theory in which mRNA export adapter proteins are recruited to the mRNA through unstructured RNA, thus serving as the signal for the recruitment of the export machinery.

\section{MATERIALS AND METHODS}

\section{Construction of in vitro transcription templates}

The histone mRNAs used in this work were derived from the mouse $\mathrm{H} 2 \mathrm{a}-614$ gene and are schematized in Figure 1. All histone mRNA transcription templates were generated by PCR, adding the T7 promoter sequence to the $5^{\prime}$ end of each amplification product. The original mouse H2a-614 clone in pUC18 (H2a-614 wt/ pUC18; Graves et al. 1985) was used for the production of fulllength transcripts ending $7 \mathrm{nt}$ past the $\mathrm{U} 7$ binding site $(\mathrm{H} 2 \mathrm{a} \mathrm{wt}$ pre-mRNA). To obtain the H2a $\Delta$ (199-309) pre-mRNA construct, precise deletion of the region between nt 199 and 309 in H2a-614/ pUC18 was performed by standard PCR techniques yielding the H2a-614 $\Delta(199-309) / p U C 18$ construct. The H2a-614 5' truncation series $(\mathrm{H} 2 \mathrm{a} \Delta 297$ and $\mathrm{H} 2 \mathrm{a} \Delta 389)$ was designed by PCR amplification of the region between either nt 298 or 390, relative to the transcription start site, and the cleavage site. The chimeric histone mRNA constructs containing H3-614 (H3-H2a) or pBlueScript (pBS1-H2a and pBS2-H2a) sequence upstream of the H2a-614 stem-loop were generated by insertion of H3-614 or pBlueScript sequence of the corresponding size into the MscI and KpnI sites or PstI and KpnI sites of the $\mathrm{H} 2 \mathrm{a} \Delta 297$ clone. H2a $\Delta 297$ has been described and was previously called H2a $\Delta 29$ (Dominski et al.
1999). The $\mathrm{H} 2 \mathrm{a} \Delta 297$ reverse-stem (rs) construct was derived from the $\mathrm{H} 2 \mathrm{a} \Delta 297$ wild-type clone and contains the reverse-stem mutation in the stem-loop (Pandey et al. 1994). The 30-nt-long wt $\left(\mathrm{SL}_{\mathrm{WT}}\right)$ and rs $\left(\mathrm{SL}_{\mathrm{RS}}\right)$ stem-loop RNAs were produced from PCR products containing the T7 promoter followed by either the wildtype or reverse stem-loop sequence. The wild-type and mutant CTE constructs were kindly provided by Bryan Cullen (Kang and Cullen 1999). The Dm H2a clone was a gift of Bob Duronio and contains the entire Drosophila $\mathrm{H} 2 \mathrm{a}$ gene inserted into pBlueScript.

The CTE and U6 $\Delta$ ss snRNA constructs were digested with XbaI and DraI, respectively, for use as in vitro transcription templates. ${ }^{32} \mathrm{P}$-labeled RNAs were produced by $\mathrm{T} 7$ transcription (Ambion) of purified PCR products or linearized DNA templates in the presence of $\left[\alpha-{ }^{32} \mathrm{P}\right] \mathrm{GTP}$. Capped RNAs were synthesized using the cap analog from Ambion. For the large-scale synthesis of RNAs, the Ribomax kit by Promega was used according to the manufacturer's protocol. To make large quantities of the short 30-nt-long stem-loop RNA, the Megashort transcription kit by Ambion was used. In all cases, transcription reactions were applied to a G-50 spin column (Pharmacia) to remove unincorporated NTPs. Transcription reactions for the production of unlabeled competitor RNAs were further processed by DNase treatment, phenol-chloroform extraction, and ethanol precipitation.

\section{Oocyte injections}

Nuclear injection of frog oocytes was carried out essentially as previously described (Jarmolowski et al. 1994). Briefly, oocyte nuclei were injected with $15 \mathrm{~nL}$ of a mixture containing $\sim 10 \mathrm{fmol}$ of the various histone mRNAs and $20 \mathrm{fmol}$ of CTE and U6 snRNA and blue dextran as a marker for successful nuclear injection. The amounts of competitor RNAs used and the temperature at which oocytes were incubated following nuclear injection are indicated in the figure legends.

RNA was prepared from the nuclear and cytoplasmic fractions by either proteinase $\mathrm{K}$ treatment in HOMO buffer ( $50 \mathrm{mM}$ Tris$\mathrm{HCl}$ at $\mathrm{pH}$ 7.4, $5 \mathrm{mM}$ EDTA, 1.5\% SDS, $300 \mathrm{mM} \mathrm{NaCl}, 1.5 \mathrm{mg} / \mathrm{mL}$ proteinase K) or by TRIzol (Invitrogen) extraction. Two uninjected oocytes were added to each nuclear fraction to facilitate the precipitation of RNA. Following proteinase K treatment, RNA was extracted with acidic phenol and precipitated with ethanol. RNA pellets were resuspended in $25 \mu \mathrm{L}$ of water to which $25 \mu \mathrm{L}$ of RNA loading dye (95\% formamide, $0.05 \%$ SDS, $0.05 \%$ xylene cyanole FF, $0.05 \%$ bromophenol blue) was added. RNAs prepared by TRIzol extraction were directly resuspended in $7 \mathrm{M}$ urea dye. Typically, one oocyte-equivalent of RNA from the nuclear and cytoplasmic fractions was resolved on an $8 \%$ acrylamide/7 M urea gel. Gels were dried and exposed to PhosphorImager screens. Quantification was performed using the ImageQuant software.

\section{RNA interference}

Production of double-stranded RNA and RNAi in Drosophila S2 cells was carried out essentially as described (Clemens et al. 2000). The primers and PCR template for making double-stranded RNA against Nxf1 were kindly provided by E. Izaurralde (Herold et al. 2001). Production of RNA needed for the S2 cell RNAi protocol was achieved using the Promega Ribomax large scale RNA synthesis kit. Following at least a $4-\mathrm{h}$ incubation at $37^{\circ} \mathrm{C}$, the sense 
and antisense strands were annealed by heating of the transcription reaction for $30 \mathrm{~min}$ at $65^{\circ} \mathrm{C}$ followed by a slow cooling to room temperature. Annealed RNAs were purified by chromatography on a G-50 spin column and precipitated with ethanol.

For the RNAi, $1 \times 10^{6} \mathrm{~S} 2$ cells/well were plated in a 6-well tissue culture dish. The cells were allowed to attach for a half-hour and were subsequently rinsed with medium lacking serum and antibiotics. One milliliter of serum and antibiotic-free medium was overlayed onto the cells. Fifteen micrograms of the dsRNA was immediately added and the cells were incubated for $45 \mathrm{~min}$ to $1 \mathrm{~h}$. Subsequently, $2 \mathrm{~mL}$ of medium containing serum and antibiotics were added to the cells. The depletion of Nxf1 was monitored by Western blot analysis following a 4-d exposure to the Nxf1 dsRNA.

\section{Extract preparation and Western blotting}

S2 cells were detached by gentle pipetting and counted. Cells were pelleted by centrifugation and washed with PBS. Extracts were prepared by detergent lysis using a buffer containing $20 \mathrm{mM}$ Tris (pH 7.5), $150 \mathrm{mM} \mathrm{NaCl}, 0.1 \% \mathrm{NP}-40$, and $1 \mathrm{mM}$ PMSF by incubation for $10 \mathrm{~min}$ at $4^{\circ} \mathrm{C}$ with gentle agitation. Lysates were cleared by centrifugation at maximum speed for $10 \mathrm{~min}$ at $4^{\circ} \mathrm{C}$. Because the depletion of Nxf1 directly affects total cellular protein levels, rather than normalizing for total protein for SDS PAGE, equivalent cell numbers for each sample were loaded instead. Proteins resolved on a $10 \%$ SDS-PAGE were transferred to nitrocellulose and probed with the polyclonal rabbit Dm Nxf1 antibody (used at a dilution of 1:2000) provided by E. Izaurralde. Detection was accomplished using an anti-rabbit IgG horseradish peroxidase conjugated antibody and an enhanced chemiluminescence system.

\section{S1 nuclease protection assay}

The 3' S1 probes for detection of the Drosophila histone H2a and mouse histone H2a-614 mRNAs have been described (Dominski et al. 2002a; Lanzotti et al. 2002). Hybridization and digestion of DNA-RNA hybrids was carried out essentially as previously described (Ingledue et al. 2000; Dominski et al. 2002a) using either one oocyte equivalent of each nuclear and cytoplasmic fraction or $1 \mu \mathrm{g}$ of total RNA. Protected fragments were resolved on an $8 \%$ acrylamide/7 $\mathrm{M}$ urea gel.

\section{mRNA FISH and transfection}

Drosophila S2 cells and HeLa cells were grown on coverslips and fixed using 3.7\% paraformaldehyde. Permeabilization was carried out using $0.5 \%$ Triton-X 100. For the oligo(dT) FISH, coverslips were washed with $6 \times \operatorname{SSPE}\left(900 \mathrm{mM} \mathrm{NaCl}, 60 \mathrm{mM} \mathrm{NaH}_{2} \mathrm{PO}_{4}, 6\right.$ $\mathrm{mM}$ EDTA at $\mathrm{pH}$ 7.4) and blocked for $30 \mathrm{~min}$ at room temperature in a humidified chamber using $5 \mu \mathrm{L}$ of blocking solution $(0.5$ $\mathrm{mg} / \mathrm{mL}$ Escherichia coli tRNA in $6 \times$ SSPE $\mathrm{pH} 7.4,5 \times$ Denhardt's solution). Subsequently, $5 \mu \mathrm{L}$ of denatured biotinylated oligo(dT) probe $(1 \mathrm{pmol} / \mu \mathrm{L}$ in $6 \times \mathrm{SSPE}$ at $\mathrm{pH} 7.4,5 \times$ Denhardt's solution $)$ was added to each coverslip. After a 1-h incubation at room temperature (in a humidified chamber), the coverslips were washed three times with $6 \times$ SSPE ( $\mathrm{pH} 7.4$ ), 0.05\% Tween-20, and, subsequently, twice with $4 \times$ SSC ( $\mathrm{pH} 7.0$ ). Coverslips were then incubated with FITC-conjugated avidin (Sigma; diluted 1:200 in $4 \times$
SSC at $\mathrm{pH} 7.0,0.05 \%$ Tween-20) for $30 \mathrm{~min}$ in a humidified chamber at room temperature. Unbound avidin was removed by washing the coverslips three times with $4 \times$ SSC ( $\mathrm{pH} 7.0$ ), $0.05 \%$ Tween-20. Cells were post-fixed with 3.7\% paraformaldehyde and counterstained with DAPI (Sigma). The coverslips were washed three times with $1 \times$ PBS and then mounted onto microscope slides in a suitable mounting medium. All images were taken using the Carl Zeiss, Inc. LSM10 confocal laser scanning microscope and LSM510 v3.2 software.

For the H2a mRNA FISH in S2 cells, following permeabilization of the cells and subsequent washing, coverslips were prehybridized for $5 \mathrm{~min}$ at $37^{\circ} \mathrm{C}$ in $50 \%$ formamide, $2 \times$ SSC, $50 \mathrm{mM}$ sodium phosphate buffer ( $\mathrm{pH} 7.0$ ), 0.05\% Tween-20. Hybridization was carried out overnight at $37^{\circ} \mathrm{C}$ using a nick-translated digoxygenin (DIG) labeled probe against the histone $\mathrm{H} 2 \mathrm{a}$ mRNA at a final concentration of $10 \mathrm{ng} / \mu \mathrm{L}$ in prehybridization buffer containing $10 \%$ dextran sulfate. The DIG-dUTP was obtained from Enzo. On the next day, the coverslips were washed at $45^{\circ} \mathrm{C}$ three times with $50 \%$ formamide, $2 \times$ SSC, $0.05 \%$ Tween- 20 and subsequently three times with $2 \times$ SSC, $0.05 \%$ Tween -20 at $45^{\circ} \mathrm{C}$. Prior to application of the anti-DIG antibody, the coverslips were washed with $4 \times$ SSC, $0.05 \%$ Tween-20 at room temperature. The coverslips were then incubated with a mouse cy3 anti-DIG antibody (Jackson ImmunoResearch; 1:200 in 4× SSC, 2\% BSA, 0.05\% Tween-20) for $1 \mathrm{~h}$ in a humidified chamber. Excess antibody was removed by washing three times with $4 \times$ SSC. Subsequently, the coverslips were incubated with a cy3 anti-mouse antibody (Jackson ImmunoResearch) for $30 \mathrm{~min}$ in a humidified chamber. The coverslips were then processed as above for washing, post-fixing, and counterstaining.

HeLa cells seeded into a 6-well plate, were transfected with $2 \mu \mathrm{g}$ of DNA corresponding to either $\mathrm{H} 2 \mathrm{a}-614 \mathrm{wt} / \mathrm{pUC} 18$ or $\mathrm{H} 2 \mathrm{a}-$ $614 \Delta(199-309) / p U C 18$ using the Lipofectamine 2000 reagent. One day post-transfection cells were fixed and permeabilized as described above. Detection of the mouse H2a-614 mRNA in HeLa cells was performed using a DIG-labeled antisense RNA probe targeting the $150 \mathrm{nt}$ downstream of the PstI site. The DIG-UTP was obtained from Enzo. Prehybridization was carried out in 50\% formamide, $4 \times$ SSC. Cells were incubated overnight at $37^{\circ} \mathrm{C}$ in hybridization solution (50\% formamide, $10 \%$ dextran sulfate, $1 \times$ Denhardt's solution, $4 \times$ SSC, $1 \mathrm{mg} / \mathrm{mL}$ E. coli tRNA) containing 1 $\mathrm{ng} / \mu \mathrm{L}$ of the DIG-labeled RNA probe. On the next day, the coverslips were washed once with $2 \times$ SSC and three times with $60 \%$ formamide, $0.2 \times \mathrm{SSC}$ at $37^{\circ} \mathrm{C}$ and processed as above for detection of the DIG-labeled probe.

\section{BrdU incorporation and detection}

S2 cells grown on coverslips were transferred to fresh medium containing $\mathrm{BrdU}$ at a final concentration of $10 \mu \mathrm{M}$ and were incubated for $2 \mathrm{~h}$. The cells were briefly washed with $1 \times$ PBS to remove the BrdU-containing medium and fixed as above. After permeabilization and washing with $1 \times$ PBS, the coverslips were incubated in $1 \mathrm{M} \mathrm{HCl}$ for $30 \mathrm{~min}$ at room temperature. The coverslips were then extensively washed (at least five times) with $1 \times$ PBS to remove any residual acid and incubated with a mouse anti-BrdU antibody (Roche, BrdU Labeling and Detection Kit I) for $30 \mathrm{~min}$ at $37^{\circ} \mathrm{C}$ in a humidified chamber. Following three washes with $1 \times$ PBS, the coverslips were incubated with a FITCconjugated anti-mouse antibody (Sigma; diluted 1:100 in 1× PBS) 
for $30 \mathrm{~min}$ in a humidified chamber at room temperature. The coverslips were subsequently washed, post-fixed, and counterstained with DAPI as described above.

\section{ACKNOWLEDGMENTS}

We thank E. Izaurralde and A. Herold (both of EMBL, Heidelberg, Germany) for providing reagents to perform RNA interference in Drosophila cells, A. Calado (Univ. of Lisbo, Portugal) for advice on in situ hybridization, and B. Cullen (Duke Univ., Durham, North Carolina) for the CTE constructs. Additionally, we thank B. Duronio (Univ. of North Carolina, Chapel Hill) for providing us with the Drosophila H2a plasmid. This work was supported by the Swiss National Science Foundation and an intramural ETH grant to U.K. and NIH grant GM 58921 to W.F.M.

Received September 27, 2004; accepted October 25, 2004.

\section{REFERENCES}

Ahmad, K. and Henikoff, S. 2002. Histone H3 variants specify modes of chromatin assembly. Proc. Natl. Acad. Sci. 99: 16477-16484.

Azzouz, T.N. and Schumperli, D. 2003. Evolutionary conservation of the U7 small nuclear ribonucleoprotein in Drosophila melanogaster. RNA 9: 1532-1541.

Bachi, A., Braun, I.C., Rodrigues, J.P., Pante, N., Ribbeck, K., von Kobbe, C., Kutay, U., Wilm, M., Gorlich, D., Carmo-Fonseca, M., et al. 2000. The C-terminal domain of TAP interacts with the nuclear pore complex and promotes export of specific CTE-bearing substrates. RNA 6: 136-158.

Braun, I.C., Rohrbach, E., Schmitt, C., and Izaurralde, E. 1999. TAP binds to the constitutive transport element (CTE) through a novel RNA-binding motif that is sufficient to promote CTE-dependent RNA export from the nucleus. EMBO J. 18: 1953-1965.

Braun, I.C., Herold, A., Rode, M., and Izaurralde, E. 2002. Nuclear export of mRNA by TAP/NXF1 requires two nucleoporin-binding sites but not p15. Mol. Cell. Biol. 22: 5405-5418.

Clemens, J.C., Worby, C.A., Simonson-Leff, N., Muda, M., Maehama, T., Hemmings, B.A., and Dixon, J.E. 2000. Use of double-stranded RNA interference in Drosophila cell lines to dissect signal transduction pathways. Proc. Natl. Acad. Sci. 97: 6499-6503.

Cullen, B.R. 2003. Nuclear RNA export. J. Cell Sci. 116: 587-597.

DeBry, R.W. and Marzluff, W.F. 1994. Selection on silent sites in the rodent H3 histone gene family. Genetics 138: 191-202.

Dominski, Z. and Marzluff, W.F. 1999. Formation of the 3' end of histone mRNA. Gene 239: 1-14.

Dominski, Z., Zheng, L.-X., Sanchez, R., and Marzluff, W.F. 1999. Stem-loop binding protein facilitates $3^{\prime}$-end formation by stabilizing U7 snRNP binding to histone pre-mRNA. Mol. Cell. Biol. 19: 3561-3570.

Dominski, Z., Erkmann, J.A., Yang, X., Sanchez, R., and Marzluff, W.F. 2002a. A novel zinc finger protein is associated with U7 snRNP and interacts with the stem-loop binding protein in the histone mRNP to stimulate 3 '-end processing. Genes \& Dev. 16: 58-71.

Dominski, Z., Yang, Y.-c., Raska, C.S., Santiago, C., Borchers, C.H., Duronio, R.J., and Marzluff, W.F. 2002b. $3^{\prime}$ end processing of Drosophila melanogaster histone pre-mRNAs: Requirement for phosphorylated Drosophila stem-loop binding protein and coevolution of the histone pre-mRNA processing system. Mol. Cell. Biol. 22: 6648-6660.

Dominski, Z., Yang, X.-c., Purdy, M., and Marzluff, W.F. 2003. Cloning and characterization of the Drosophila U7 small nuclear RNA. Proc. Natl. Acad. Sci. 100: 9422-9427.

Eckner, R., Ellmeier, W., and Birnstiel, M.L. 1991. Mature mRNA 3' end formation stimulates RNA export from the nucleus. EMBO J. 10: 3513-3522.

Erkmann, J.A. and Kutay, U. 2004. Nuclear export of mRNA: From the site of transcription to the cytoplasm. Exp. Cell Res. 296: 12-20.

Fischer, U., Huber, J., Boelens, W.C., Mattaj, I.W., and Luhrmann, R. 1995. The HIV-1 Rev activation domain is a nuclear export signal that accesses an export pathway used by specific cellular RNAs. Cell 82: $475-483$

Fornerod, M., Ohno, M., Yoshida, M., and Mattaj, I.W. 1997. CRM1 is an export receptor for leucine-rich nuclear export signals. Cell 90: 1051-1060.

Fribourg, S., Braun, I.C., Izaurralde, E., and Conti, E. 2001. Structural basis for the recognition of a nucleoporin FG repeat by the NTF2like domain of the TAP/p15 mRNA nuclear export factor. Mol. Cell 8: 645-656.

Fried, H. and Kutay, U. 2003. Nucleocytoplasmic transport: Taking an inventory. Cell Mol. Life Sci. 60: 1659-1688.

Gatfield, D. and Izaurralde, E. 2002. REF1/Aly and the additional exon junction complex proteins are dispensable for nuclear mRNA export. J. Cell Biol. 159: 579-588.

Graves, R.A., Wellman, S.E., Chiu, I.M., and Marzluff, W.F. 1985. Differential expression of two clusters of mouse histone genes. $J$. Mol. Biol. 183: 179-194.

Gruter, P., Tabernero, C., von Kobbe, C., Schmitt, C., Saavedra, C., Bachi, A., Wilm, M., Felber, B.K., and Izaurralde, E. 1998. TAP, the human homolog of Mex67p, mediates CTE-dependent RNA export from the nucleus. Mol. Cell 1: 649-659.

Herold, A., Klymenko, T., and Izaurralde, E. 2001. NXF1/p15 heterodimers are essential for mRNA nuclear export in Drosophila. RNA 7: 1768-1780.

Herold, A., Teixeira, L., and Izaurralde, E. 2003. Genome-wide analysis of nuclear mRNA export pathways in Drosophila. EMBO J. 22: 2472-2483.

Huang, Y. and Carmichael, G.G. 1997. The mouse histone H2a gene contains a small element that facilitates cytoplasmic accumulation of intronless gene transcripts and of unspliced HIV-1-related mRNAs. Proc. Natl. Acad. Sci. 94: 10104-10109.

Huang, Y. and Steitz, J.A. 2001. Splicing factors SRp20 and 9G8 promote the nucleocytoplasmic export of mRNA. Mol. Cell 7: 899905.

Huang, Y., Gattoni, R., Stevenin, J., and Steitz, J.A. 2003. SR splicing factors serve as adapter proteins for TAP-dependent mRNA export. Mol. Cell 11: 837-843.

Ingledue III, T.C., Dominski, Z., Sanchez, R., Erkmann, J.A., and Marzluff, W.F. 2000. Dual role for the RNA binding domain of Xenopus laevis SLBP1 in histone pre-mRNA processing. RNA 6: $1635-1648$.

Izaurralde, E., Lewis, J., Gamberi, C., Jarmolowski, A., McGuigan, C., and Mattaj, I.W. 1995. A cap-binding protein complex mediating U snRNA export. Nature 376: 709-712.

Jarmolowski, A., Boelens, W.C., Izaurralde, E., and Mattaj, I.W. 1994. Nuclear export of different classes of RNA is mediated by specific factors. J. Cell Biol. 124: 627-635.

Kang, Y. and Cullen, B.R. 1999. The human Tap protein is a nuclear mRNA export factor that contains novel RNA-binding and nucleocytoplasmic transport sequences. Genes \& Dev. 13: 1126-1139.

Katahira, J., Strasser, K., Podtelejnikov, A., Mann, M., Jung, J.U., and Hurt, E. 1999. The Mex67p-mediated nuclear mRNA export pathway is conserved from yeast to man. EMBO J. 18: 2593-3609.

Kataoka, N., Yong, J., Narry Kim, V., Velazquez, F., Perkinson, R.A., Wang, F., and Dreyfuss, G. 2000. Pre-mRNA splicing imprints mRNA in the nucleus with a novel RNA-binding protein that persists in the cytoplasm. Mol. Cell 6: 673-682.

Kataoka, N., Diem, M.D., Narry Kim, V., Yong, J., and Dreyfuss, G. 2001. Magoh, a human homologue of Drosophila mago nashi protein, is a component of the splicing-dependent exon-exon junction complex. EMBO J. 20: 6424-6433.

Lanzotti, D.J., Kaygun, H., Yang, X., Duronio, R.J., and Marzluff, W.F. 2002. Developmental control of histone mRNA and dSLBP syn- 
thesis during Drosophila embryogenesis and the role of dSLBP in histone mRNA $3^{\prime}$ end processing in vivo. Mol. Cell. Biol. 22: 22672282.

Le Hir, H., Izaurralde, E., Maquat, L.E., and Moore, M.J. 2000. The spliceosome deposits multiple proteins 20-24 nucleotides upstream of mRNA exon-exon junctions. EMBO J. 19: 6860-6869.

Le Hir, H., Gatfield, D., Braun, I.C., Forler, D., and Izaurralde, E. 2001a. The protein Mago provides a link between splicing and mRNA localization. EMBO Rep. 21: 1119-1124.

Le Hir, H., Gatfield, D., Izaurralde, E., and Moore, M.J. 2001b. The exon-exon junction complex provides a binding platform for factors involved in mRNA export and nonsense-mediated decay. EMBO J. 20: 4987-4997.

Lei, E.P., Krebber, H., and Silver, P.A. 2001. Messenger RNAs are recruited for nuclear export during transcription. Genes \& Dev. 15: 1771-1782.

Levesque, L., Guzik, B., Guan, T., Coyle, J., Black, B.E., Rekosh, D., Hammarskjold, M.-L., and Paschal, B.M. 2001. RNA export mediated by Tap involves NXT1-dependent interactions with the nuclear pore complex. J. Biol. Chem. 276: 44953-44962.

Longman, D., Johnstone, I.L., and Caceres, J.F. 2003. The Ref/Aly proteins are dispensable for mRNA export and development in Caenorhabditis elegans. RNA 9: 881-891.

Luo, M.-j. and Reed, R. 1999. Splicing is required for rapid and efficient mRNA export in metazoans. Proc. Natl. Acad. Sci. 96: 1493714942.

Marzluff, W.F., Gongidi, P., Woods, K.R., Jin, J., and Maltais, L.J. 2002. The human and mouse replication-dependent histone genes. Genomics 80: 487-498.

Masuyama, K., Taniguchi, I., Kataoka, N., and Ohno, M. 2004. RNA length defines RNA export pathway. Genes \& Dev. 18: 2074-2085.

Ohno, M., Segref, A., Kuersten, S., and Mattaj, I.W. 2002. Identity elements used in export of mRNAs. Mol. Cell 9: 659-671.

Pandey, N.B., Williams, A.S., Sun, J.H., Brown, V.D., Bond, U., and Marzluff, W.F. 1994. Point mutations in the stem-loop at the $3^{\prime}$ end of mouse histone mRNA reduce expression by reducing the efficiency of 3' end formation. Mol. Cell. Biol. 14: 1709-1720.

Pasquinelli, A.E., Ernst, R.K., Lund, E., Grimm, C., Zapp, M.L., Rekosh, D., Hammarskjold, M.-L., and Dahlberg, J.E. 1997. The constitutive transport element (CTE) of Mason-Pfizer monkey virus (MPMV) accesses a cellular mRNA export pathway. EMBO J. 16: 7500-7510.

Redon, C., Pilch, D., Rogakou, E., Sedelnikova, O., Newrock, K., and Bonner, W. 2002. Histone H2a variants H2AX and H2AZ. Curr. Opin. Genet. Dev. 12: 162-169.

Rodrigues, J.P., Rode, M., Gatfield, D., Blencowe, B.J., Carmo-Fonseca, M., and Izaurralde, E. 2001. REF proteins mediate the export of spliced and unspliced mRNAs from the nucleus. Proc. Natl. Acad. Sci. 98: 1030-1035.

Sanchez, R. and Marzluff, W.F. 2002. The stem-loop binding protein is required for efficient translation of histone mRNA in vivo and in vitro. Mol. Cell. Biol. 22: 7093-7104.

Schaal, T.D. and Maniatis, T. 1999. Selection and characterization of pre-mRNA splicing enhancers: Identification of novel SR protein-specific enhancer sequences. Mol. Cell. Biol. 19: 17051719.

Schochetman, G. and Perry, R.P. 1972. Early appearance of histone messenger RNA in polyribosomes of cultured L cells. J. Mol. Biol. 63: 591-596.

Segref, A., Sharma, K., Doye, V., Hellwig, A., Huber, J., Luhrmann, R., and Hurt, E. 1997. Mex67p, a novel factor for nuclear mRNA export, binds to both poly $(\mathrm{A})+\mathrm{RNA}$ and nuclear pores. EMBO J. 16: 3256-3271.

Strasser, K. and Hurt, E. 2000. Yra1p, a conserved nuclear RNAbinding protein, interacts directly with Mex67p and is required for mRNA export. EMBO J. 19: 410-420.

Strasser, K., Masuda, S., Mason, P., Pfannstiel, J., Oppizzi, M., Rodriguez-Navarro, S., Rondon, A.G., Aguilera, A., Struhl, K., Reed, R., et al. 2002. TREX is a conserved complex coupling transcription with messenger RNA export. Nature 417: 304-308.

Stutz, F. and Izaurralde, E. 2003. The interplay of nuclear mRNP assembly, mRNA surveillance and export. Trends Cell Biol. 13: 319-327.

Stutz, F., Bachi, A., Doerks, T., Braun, I.C., Seraphin, B., Wilm, M., Bork, P., and Izaurralde, E. 2000. REF, an evolutionarily conserved family of hnRNP-like proteins, interacts with TAP/Mex67p and participates in mRNA nuclear export. RNA 6: 638-650.

Wang, Z.F., Ingledue, T.C., Dominski, Z., Sanchez, R., and Marzluff, W.F. 1999. Two Xenopus proteins that bind the 3' end of histone mRNA: Implications for translational control of histone synthesis during oogenesis. Mol. Cell. Biol. 19: 835-845.

Wells, D. and Kedes, L. 1985. Structure of a human histone cDNA: Evidence that basally expressed histone genes have intervening sequences and encode polyadenylated mRNAs. Proc. Natl. Acad. Sci. 82: 2834-2838.

Wiegand, H.L., Coburn, G.A., Zeng, Y., Kang, Y., Bogerd, H.P., and Cullen, B.R. 2002. Formation of Tap/NXT1 heterodimers activates Tap-dependent nuclear mRNA export by enhancing recruitment to nuclear pore complexes. Mol. Cell. Biol. 22: 245-256.

Williams, A.S., Ingledue III, T.C., Kay, B.K., and Marzluff, W.F. 1994. Changes in the stem-loop at the $3^{\prime}$ terminus of histone mRNA affects its nucleocytoplasmic transport and cytoplasmic regulation. Nucleic Acids Res. 22: 4660-4666.

Zenklusen, D., Vinciguerra, P., Wyss, J.-C., and Stutz, F. 2002. Stable mRNP formation and export require cotranscriptional recruitment of the mRNA export factors Yralp and Sub2p by Hprlp. Mol. Cell. Biol. 22: 8241-8253.

Zhou, Z., Luo, M.-j., Strasser, K., Katahira, J., Hurt, E., and Reed, R. 2000. The protein Aly links pre-messenger-RNA splicing to nuclear export in metazoans. Nature 407: 401-405. 

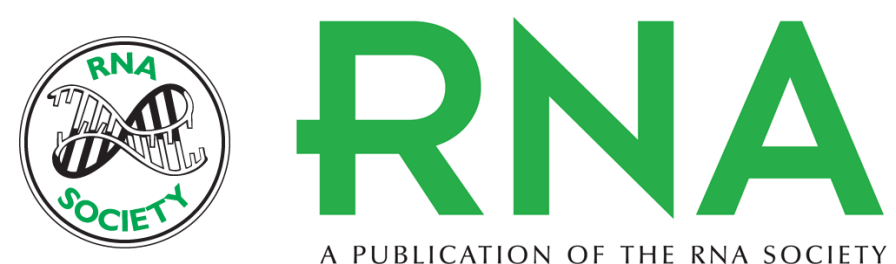

A PUBLICATION OF THE RNA SOCIETY

\section{Nuclear export of metazoan replication-dependent histone mRNAs is dependent on RNA length and is mediated by TAP}

JUDITH A. ERKMANN, RICARDO SÀNCHEZ, NATHALIE TREICHEL, et al.

RNA 2005 11: 45-58

References This article cites 63 articles, 41 of which can be accessed free at: http://rnajournal.cshlp.org/content/11/1/45.full.html\#ref-list-1

License

Email Alerting

Receive free email alerts when new articles cite this article - sign up in the box at the Service top right corner of the article or click here. 